\title{
A Case Study of the Effects of Respiration Trainers on Vocal Aerobic Treatment Program
}

\author{
Ha-Neul Kanga, Jae-Yeon Yoo ${ }^{\text {b }}$ \\ ${ }^{a}$ Graduate Program in Speech-Language Pathology, Honam University, Gwangju, Korea \\ ${ }^{b}$ Department of Speech \& Language Pathology, Honam University, Gwangju, Korea
}

\author{
Correspondence: Jae-Yeon Yoo, $\mathrm{PhD}$ \\ Department of Speech \& Language Pathology, \\ Honam University, 417 Eodeung-daero, \\ Gwangsan-gu, Gwangju 62399, Korea \\ Tel: +82-62-940-5546 \\ Fax: +82-62-940-5196 \\ E-mail: slpyoo@hanmail.net \\ Received: January 5, 2019 \\ Revised: February 13, 2019 \\ Accepted: February 23, 2019
}

This work is based on the master's thesis of the first author:
Objectives: The purpose of this study was to investigate the effect of respiration trainers on voice enhancement during a vocal aerobic treatment (VAT) program developed for holistic voice therapy. Methods: This study consisted of four patients ( 3 females and 1 male) diagnosed with hyperfunctional dysphonia. The program involved activities including relaxation, breathing, and phonation exercises, as well as a speaking stage. In order to examine the degree of voice improvement, the changes in the acoustic and aerodynamic parameters were compared pre and post intervention. Voice questionnaires and an auditory evaluation were also evaluated using a pre-post process. Results: As a result of this program, each of the subject's pitch and speaking fundamental pitch increased overall. The pitch range was widened, and their voice quality improved based on the reduced values of their acoustic parameters. In addition, the aerodynamic parameters and breathing ability of the subjects improved. The Voice Handicap Index of the subjects decreased and their Korean-Voice Related Quality of Life increased. Moreover, their voice satisfaction also improved. The subjects were more comfortable and projected a softer voice. The overall auditory voice improved. Conclusion: The VAT program using respiration trainers was found to be effective in improving the voice of subjects with hyperfunctional dysphonia, and therefore it can be considered a useful program in the voice therapy field. In the future, if the program is applied to a large sample of heterogeneous subjects, more useful information for voice therapy can be obtained.

Keywords: Respiration trainer, Vocal aerobic treatment (VAT) program, Voice therapy, Hyperfunctional dysphonia
음성위생 및 음성치료에 대한 관심은 음성장애인뿐만 아니라 직 업적 음성사용자와 일반인 등에서도 높아지고 있다. 음성치료는 이비인후과 전문의가 실시하는 의학적 치료와 음성치료 전문가 및 언어재활사가 실시하는 행동적 치료로 구분된다. 행동적 치료는 음성패턴의 변화를 중요시하며 이는 간접치료와 직접치료로 나누 어볼 수 있다. 간접치료는 음성위생 프로그램을 통해 음성장애를 유발시킬 수 있는 요인들을 관리하는 것이고 직접치료는 음성에 부 정적인 영향을 주는 발성습관을 바꾸는 방법을 제시하여 음질과 후두의 병리적인 상태를 개선하는 데 목적이 있다. 대표적인 직접 치료는 대증치료 방법과 총체적 음성치료(holistic voice therapy) 등이 있다. 총체적 음성치료는 음성산출의 하위체계인 호흡, 발성,
공명 등을 모두 통합하여 전반적으로 음성산출 수준 향상을 목표 로 하는 치료로 장애 음성치료뿐만 아니라 정상 음성 향상에도 유 용하다(Stemple, Lee, D’Amico, \& Pickup, 1994). 총체적 음성치료 는 성대기능훈련(vocal function exercise, VFE), 악센트기법(accent method), 공명음성치료(resonant voice therapy), 리실버만 음성치 료(Lee Sliverman voice treatment), 반폐쇄 성도훈련(semi-occluded vocal tract exercise, SOVTE) 등이 있다.

악센트기법과 성대기능훈련을 기초한 총체적 음성관리 프로그 램은 직업적 음성사용자들의 음질과 성대진동을 개선시키고 향상 된 음성을 유지시키는 데 효과적인 것으로 보고하였고(Han \& Jeong, 2002), 자가보고 음성증상의 향상에도 효과적인 것으로 나타났다 
(Gillivan-Murphy, Drinnan, O’Dwyer, Ridha, \& Carding, 2006; Roy et al., 2001). 또한 반폐쇄 성도훈련의 한 종류인 LaxVox는 연 축성발성장애 환자의 기본주파수(fundamental frequency, Fo), Jitter, Shimmer, 최대 음역 등 음향학적 매개변수와 최대연장발성 (maximum phonation time, MPT)을 향상시키고 GRBAS의 목쉰 음성 $(\mathrm{G})$, 쥐어짜는 음성(S)과 음성장애지수를 개선시킨다고 보고 하였다(Lim, Choi, Kim, \& Choi, 2016). 이처럼, 총체적 음성치료는 호흡 및 발성능력을 개선시켜 음성을 향상시키는 데 효과적이다.

최근에는 Yoo와 Lee (2018)가 총체적 음성치료로 성대에어로빅 치료(vocal aerobic treatment, VAT)를 개발하였으며 이는 이완, 호 흡, 발성, 발화단계로 이루어져 있다. 이완단계는 가벼운 스트레칭 을 통해 신체의 긴장도를 낮추는 활동으로 몸 스트레칭, 후두마사 지 등으로 구성되어 있으며 호흡단계는 복부 횡격막 호흡훈련을 통해 대상자의 호흡능력을 강화시키는 활동과 신체 움직임을 동반 한 호흡훈련, 허밍을 동반한 호흡훈련 등으로 구성되어 있다. 발성 단계는 SOVTE와 활창하기, 빨대발성 등을 활용하여 발성훈련을 실시한다. 마지막 발화단계에서는 최적의 음도, 강도를 유지하면서 적절한 말속도와 쉼을 사용하여 발화하도록 한다.

VAT는 소프라노 성악가의 음도 및 음향학적 매개변수(Jitter, Shimmer, NHR), 음역의 범위를 향상시키는 데 효과적이었다. 또한 치료 후, 가창음성장애지수(SVHI) 점수가 낮아져 본인의 음성 개선 에 대한 만족도가 높아진 것으로 나타났다(Yoo \& Lee, 2018). VAT는 호흡부터 발화단계까지 체계적으로 훈련함으로써 음성개선뿐만 아 니라 건강한음성을 유지 및 관리하는 데 유용하게사용할수 있다.

또한 SOVTE에는 입술트릴, 혀트릴, 허밍, 빨대발성, LaxVox, 양 순유성마찰음발성 등이 있다. SOVTE는 후두의 위치를 내려주고 인두를 확장하여 후두주위의 이완을 유도한다. SOVTE에서 사용 되는 테크닉에 따라 성대의 접촉률이 다소 차이가 있을 수 있는데, 도구를 사용하지 않는 SOVTE 테크닉인 입술트릴과 혀트릴은 다 른 SOVTE 테크닉에 비해 성대접촉률(CQ)이 가장 낮아 성대내전 을 감소시키는 데 적절하다(Guzman et al., 2015). 이 연구결과를 토 대로 본다면, 치료의 목표가 성대접촉률을 높이느냐 낮추느냐에 따라 SOVTE 테크닉을 선택적으로 적용할 필요성이 있다. 그리고 빨대발성이나 LaxVox처럼 도구를 사용하는 치료방법과 입술트릴, 혀트릴, 양순유성마찰발성 등의 도구를 사용하지 않는 치료방법에 따라 성대접촉의 정도가 차이가 있을 수 있다는 점도 고려할 필요 가 있다. 따라서 SOVTE의 한 가지 방법으로 호흡훈련기를 통한 호 흡훈련에서 호기압의 설정에 따라 성대내전에는 어떤 차이가 있는 지를 살펴볼 필요가 있을 것이다.

음성산출 하위기제인 호흡과 발성기관은 서로 상호작용하여 음
성을 산출하고 이 중 하나의 기능이 비정상적이거나 불충분할 때 음성산출에 영향을 준다. 특히 호흡은 발성을 위한 기본적인 요소 로 호흡이 부족하면 음성에 문제가 생길 수 있다. 이에 최근에는 공 학의 발전으로 호흡훈련기를 활용한 음성치료가 이루어지고 있다. 호흡훈련기인 expiratory muscle strength trainer (EMST)를 음성 피로와 양성 성대병변이 있는 직업적 음성사용자들에게 각각 사용 한 호흡근력 강화훈련과 전통적인 음성치료를 실시한 결과, 치료 후 호흡근력 강화훈련 집단에서 최대호흡압력(maximal expiratory pressure, MEP), $\mathrm{P}_{\text {sub }}$, 음역대, $\mathrm{VHI}$, 음성평가척도(vocal rating scale) 등의 유의한 개선이 나타났다(Wingate, Brown, Shrivastav, Davenport, \& Sapienza, 2007). 이는 호흡훈련기기가 음성관련 장 애의 정도를 줄이기 위해 사용될 수 있는 음성치료 도구라는 것을 보여주며 Wingate 등(2007)은 전통적인 음성치료와 호흡근력 강 화훈련을 함께 실시하는 것이 단일 음성치료보다 음성을 개선시키 는 데 유용하다고 하였다.

한편, 국외에 비해 국내에서는 호흡훈련기의 개발 보급이 미비한 편이고 음성치료 분야보다 재활치료 분야에서 신경학적 질환으로 호흡능력이 저하된 대상자들의 호흡능력을 향상시키기 위해 제한 적으로 사용되고 있다. 만성 뇌졸중 환자를 대상으로 호흡재활치 료 장비인 Threshold inspiratory muscle trainer (Respironics Inc., Cedar Grove, NJ, USA)를 활용하여 흡기근 강화훈련의 발성수행 능력을 살펴본 결과, MPT와 일련 운동속도가 향상되었다고 보고 하였고(Huh, 2017), EMST도 파킨슨병 환자들의 MEP를 증가시켜 구어 호흡과 폐활량을 향상시키는 데 유용한 것으로 나타났다(Darling-White \& Huber, 2017). 또한 호기압 역치 훈련장치(expiratory pressure threshold training device)를 이용한 음성치료는 정상 노 인들의 MEP와 최대 음성 강도의 구강내압(intraoral pressure)을 유의하게 향상시키는 것으로 보고하였다(Kim \& Sapienza, 2006). 이러한 결과들을 토대로 호흡훈련기를 음성장애인들에게 적용하 여 발성에 기초가 되는 호흡능력을 향상시킬 필요가 있다.

이에 본 연구는 호흡훈련기를 활용한 호흡 및 발성훈련의 필요 성을 제시하며 재활치료 분야에서 널리 사용되고 있는 호흡훈련기 를 최근에 총체적 음성치료로 개발된 성대에어로빅치료(VAT)의 호흡 및 발성단계에 접목시켜 활용하고자 하였다. 이러한 훈련은 음성장애인의 호흡능력과 호기압의 조절능력을 향상시키고 음도 및 강도를 변화시켜 음성개선을 기대할 수 있고 임상에서 활용할 수 있는 음성치료 프로그램을 개발하는 데 도움이 될 것이다. 따라 서 본 연구는 호흡훈련기를 활용한 VAT 프로그램이 음성 개선에 어떤 효과가 있는지 음향학적, 공기역학적, 청지각적, 음성설문 등 으로 알아보고자 하였다. 


\section{연구방법}

\section{연구대상}

본 연구의 대상은 이비인후과에서 후두내시경 소견상 과기능 음 성장애로 진단된 성인 4 명(여성 3명, 남성 1명)을 대상으로 하였다. 대상자의 선정기준은 다음과 같았다. (1) 만성 호흡기질환 또는 만 성적인 상기도감염 소견이 없는 사람, (2) 기타 질병으로 장기간 또 는 최근에 약물 복용이 없는 사람, (3) 과거에 후두 관련 수술 또는 음성치료를 받은 적이 없는 사람, (4) 인지에 문제가 없는 사람, (5) 다른 언어문제나 청력에 손실이 없는 사람, (6) 흡연이나 음주를 하 지 않는 사람이다.

위의 기준에 따라 본 연구에 참여한 대상자의 일반적인 정보는 Table 1과같다.

\section{연구절차}

본 연구는 2018년 8월부터 11월까지 실시하였으며 주 2회 간격으 로 총 12-16회기의 치료를 진행하였다. 평가는 사전평가와 4 회기마 다 중재평가를 실시하였고 사후평가는 12 회기 또는 16 회기의 치료 종결 후 1 주일 이후에 실시하였다. 사전단계에서는 사전평가로 음 향학적 평가 및 공기역학적 평가, 음성설문지, 청지각적 평가를 실 시하고 대상자들에게 음성과 관련된 문제와 호흡자세, 호흡훈련기 등에 대해 설명하였다. 중재단계에서는 음성치료 프로그램을 각 세 션당 약 40 분 정도 진행하고 약 10 분 동안 상담을 진행하였다. 음성 개선의 변화를 알아보기 위해 중간평가로 4 회기마다 음향학적 평 가 및 공기역학적 평가를 실시하였다. 사후단계에서는 사전평가와 동일하게 평가를 실시하였으며 개선된 음성을 유지할 수 있도록 상 담을 진행하였다.

\section{호흡훈련기를 활용한 VAT 프로그램}

본 연구의 호흡흔련기를 활용한 VAT 프로그램은 VAT 개발 및 적용 연구(Yoo \& Lee, 2018)를 참고하여 구성하였다. 먼저 치료 실 시 이전에 호흡훈련기의 사용방법을 설명하고 호흡 및 발성을 연습 해보도록 하였다.

음성치료 프로그램의 첫 번째는 이완단계로 목과 어깨주변을 스
트레칭하고 후두마사지를 실시하여 근육을 이완하도록 하였다. 두 번째는 호흡단계로 복식호흡을 실시한 후 이 복식호흡에 집중하면 서 호흡훈련기 불기활동을 진행하였다. 세 번째는 발성단계로 호흡 훈련기를 불면서 모음 $/ \mathrm{u} /$ 로 소리내며 연장발성하고 활창을 실시하 였다. 앞선 활동이 적응되면 키보드로 각 대상자에게 맞는 5 음계를 제공하여 그 음에 맞추어 호흡훈련기로 발성하도록 하였다. 5음계 발성은 남성의 경우 $100-150 \mathrm{~Hz}$, 여성의 경우 $200-250 \mathrm{~Hz}$ 범위에서 연습하였다. 이후 5 음계와 노래를 활용하여 호흡훈련기로 멜로디 발성을 하였다. 그 다음 호흡훈련기를 불다가 떼면서 호흡훈련기를 부는 느낌으로 부드럽게 다양한 모음을 연장발성하였다. 마지막 발 화단계에서는 적절한 말속도, 쉼, 자연스러운 운율, 최적 음도 및 강 도를 유지하면서 부드러운 단어 및 문장, 압력자음 단어 및 문장을 발화하도록 연습하였다. 각 활동의 난이도는 MPT를 길게 하고 호 기압을 높게 설정하는 것으로 조절하였다. 대상자가 해당 활동을 어려워할 경우, 호기압을 조금 약하게 그리고 연장발성 시간을 조 금 짧게 설정하여 활동 난이도를 낮추어 집중적인 연습을 한 후 모 음 $/ \mathrm{u} /$ 를 부드럽게 발성하도록 하였다. 구체적인 호흡훈련기를 활용 한 VAT프로그램 절차 및 활동 내용은 Appendix 1에 제시하였다.

\section{실험도구}

\section{호흡훈련기}

양압호기 호흡기(Threshold PEP)

Threshold PEP (Threshold positive expiratory pressure device; Respironics, Murrysville, PA, USA)는 양압 호기 호흡기로서 기도 중앙과 주변 기능을 향상시키고 효과적인 호흡근육을 훈련하도록 도와주어 호흡 패턴방식을 향상시키는 도구로 개발되었다(Fernandes, Martins, \& Bonvent, 2007; Johnston, James, \& Mackney, 2013; Philips Respironics, 2013). 또한 호흡근에 하중으로 주는 스 프링 밸브가 장착되어 있어 환자 개개인에 맞도록 호기압을 조절하 여 훈련할 수 있다. 일방향 스프링 밸브(flow-independent one-way valve)는 일관된 저항력을 일으켜 조절 가능한 압력값으로 세팅할 수 있으며, 호기압은 5-20 $\mathrm{cmH}_{2} \mathrm{O}$ 까지 조절할 수 있다. 이러한 Threshold PEP를 이용하여 대상자의 호흡문제를 확인하고 발화 할 때 필요한 호기압을 조절하여 호흡 및 발성훈련에 활용함으로

Table 1. Subjects' characteristics

\begin{tabular}{|c|c|c|c|c|c|c|}
\hline Subject & Gender/Age (yr) & Job & Diagnosis & Voice symptoms & Period of onset (mo) & GRBAS scale \\
\hline A & $F / 22$ & Student & Vocal nodules & Rough & 24 & $\mathrm{G}_{2} \mathrm{R}_{2} \mathrm{~B}_{1} \mathrm{~A}_{0} \mathrm{~S}_{1}$ \\
\hline B & $F / 45$ & Counselor & Vocal nodules & Rough, strained & 48 & $\mathrm{G}_{2} \mathrm{R}_{2} \mathrm{~B}_{2} \mathrm{~A}_{0} \mathrm{~S}_{1}$ \\
\hline C & $F / 35$ & Soprano singer & Vocal nodules & Breathy, low pitch & 48 & $\mathrm{G}_{1} \mathrm{R}_{1} \mathrm{~B}_{2} \mathrm{~A}_{0} \mathrm{~S}_{1}$ \\
\hline$D$ & $\mathrm{M} / 37$ & Academy lecturer & Ventricular dysphonia & Rough, strained & 36 & $\mathrm{G}_{3} \mathrm{R}_{3} \mathrm{~B}_{1} \mathrm{~A}_{1} \mathrm{~S}_{2}$ \\
\hline
\end{tabular}


써 호흡능력을 증진시키고 대상자에게 부는 느낌의 생체 피드백을 제공하고자 하였다. 양압 호기 호흡기는 Figure 1에 제시하였다.

\section{호흡근력강화훈련기(EMST 150)}

EMST150 (Aspire Products, Gainesville, FL, USA)은 호기근력 강화훈련기로 기침과 삼킴기능 그리고 목소리 강도 등을 향상시키 면서 호흡능력을 향상시킨다(Aspire, 2018). 이 기기는 호흡능력을 강화시키기 위해 재활치료 분야에서 파킨슨병, 뇌졸중, 다발성경화 증 등의 다양한 신경계질환 환자에게 많이 사용되며(Darling-White \& Huber, 2017) 강한 호기력을 필요로 하는 악기 연주자나 운동선

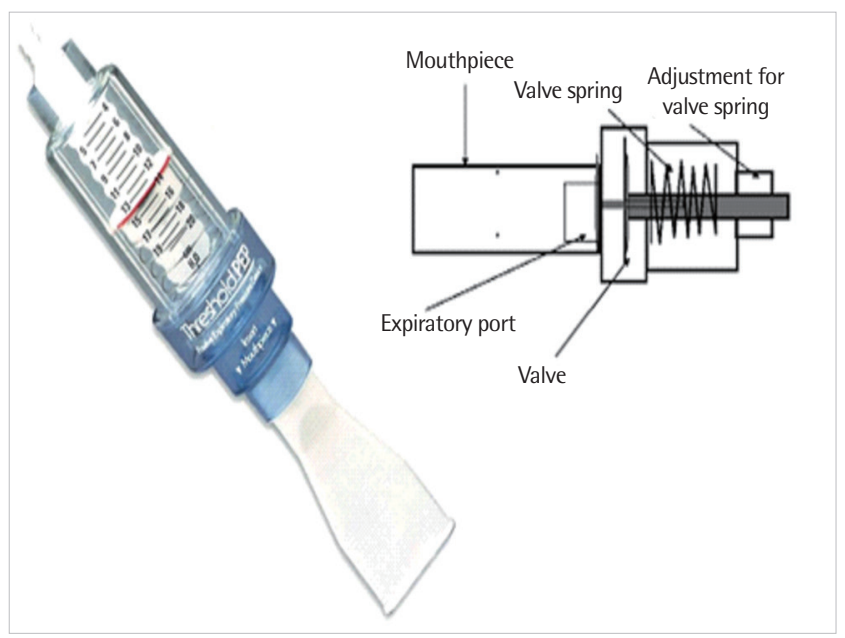

Figure 1. Threshold positive expiratory pressure device (Threshold PEP).
수 등이 사용하기도 한다. EMST150은 호기력을 증가시킴으로써 말 산출과 관련된 호흡관련 기능을 개선하는 데 유용하며 개개인 의 맞도록 호기압을 조절하여 훈련할 수 있다. 호기압은 밸브로 조 절 가능한 압력값으로 세팅할 수 있으며, 30-120 $\mathrm{cmH}_{2} \mathrm{O}$ 까지 조절 가능하다. 본 연구에서 EMST의 호기압은 30-45 $\mathrm{cmH}_{2} \mathrm{O}$ 로 조절하 여 사용하였고 이는 발성할 때 필요한 호기압보다 높으므로 호흡 훈련에만 적용하였다. 이를 통해 일정한 호기압을 유지하면서 불기 활동을 통해 호기근육의 기능을 향상시키고자 하였다. 호흡근력강 화훈련기는 Figure 2에 제시하였다.

본 연구에서는 호흡훈련기로 PEP와 EMST 두 가지를 사용하였 고 $\mathrm{PEP}$ 는 호기압을 5-20 $\mathrm{cmH}_{2} \mathrm{O}$ 까지 세팅할 수 있으며, EMST는 30-120 $\mathrm{cmH}_{2} \mathrm{O}$ 로 세팅할 수 있다. 호흡훈련단계는 낮은 호기압에 서부터 높은 호기압으로 점차적으로 난이도를 조정하면서 호흡능

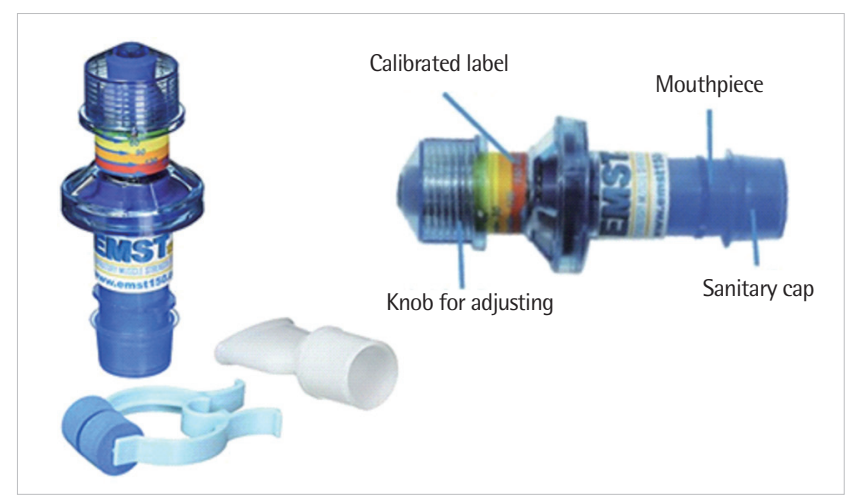

Figure 2. Expiratory muscle strength trainer (EMST150).

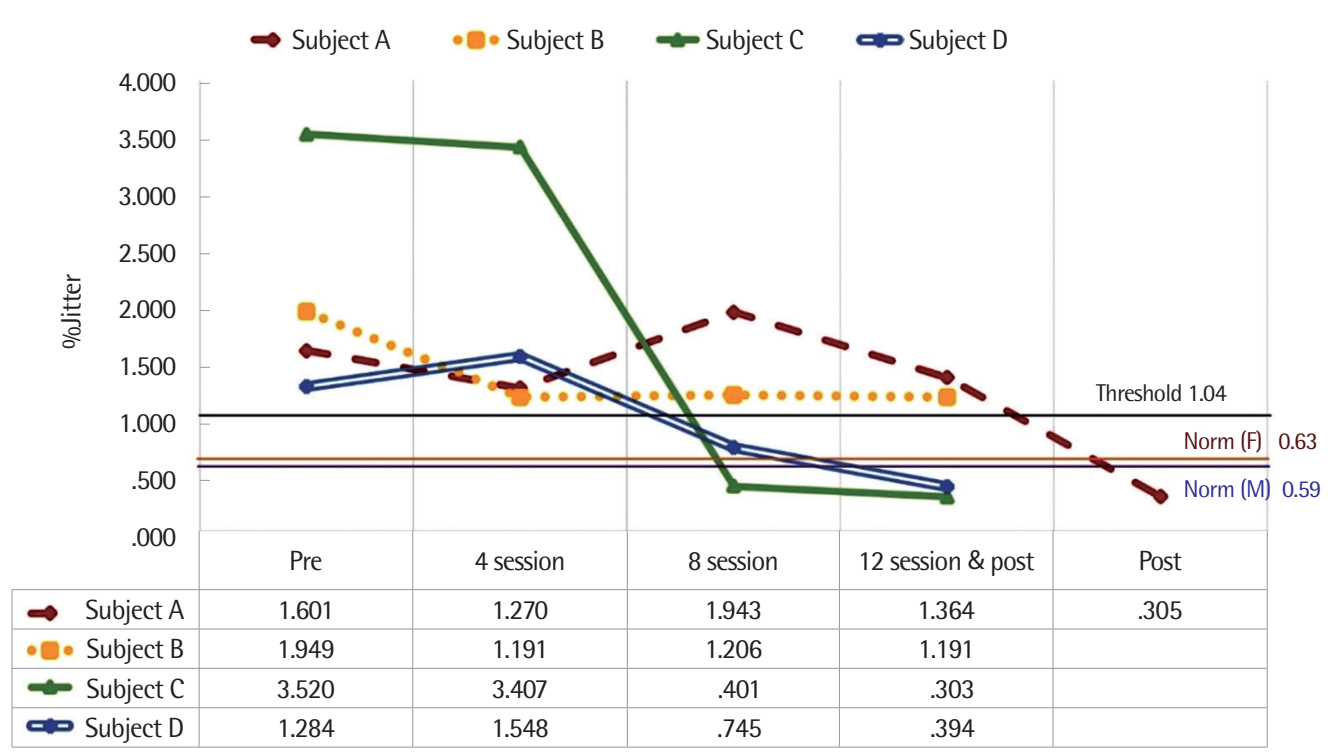

Figure 3. The acoustic parameter results (\%Jitter). 
력을 향상시키는 데 초점을 두었다. 따라서 본 연구는 두 가지 호흡 훈련기를 사용하여 5-45 $\mathrm{cmH}_{2} \mathrm{O}$ 까지 $5 \mathrm{cmH}_{2} \mathrm{O}$ 의 단위로 점차적 으로 목표 호기압을 높게 설정하여 호흡훈련을 실시하였다.

\section{평가도구}

\section{음향학적 평가}

대상자의 치료 전후 음질의 변화를 확인하기 위해 음향학적 검 사를 시행하였다. 음성분석은 Computerized Speech Lab (CSL, Model 4305; KayPENTAX)의 multi-dimensional voice program (MDVP)
을 사용하였고, 녹음 시 마이크는 대상자의 입으로부터 $10 \mathrm{~cm}$ 떨어 진 곳에 위치시키고 대상자가 평상시 사용하는 편안한 음도와 강 도로 모음 /a/를 3초 이상 발성하도록 하였다. 분석은 녹음한 구간 중 1.5 초를 선택하여 $\mathrm{F}_{0}, \% \mathrm{Jitter} \% \mathrm{Shimmer}, \mathrm{NHR}$ 을 측정하였다 (Figures 3-5).

또한 대상자의 치료 전후 발화에서의 습관적 음도를 측정하기 위해 CSL의 real-time pitch를 사용하여 발화기본주파수(speaking fundamental frequency, SFF)를 알아보았다. 마이크는 대상자의 입 으로부터 약 $10 \mathrm{~cm}$ 거리에 위치시키고 대상자가 평상시 사용하는

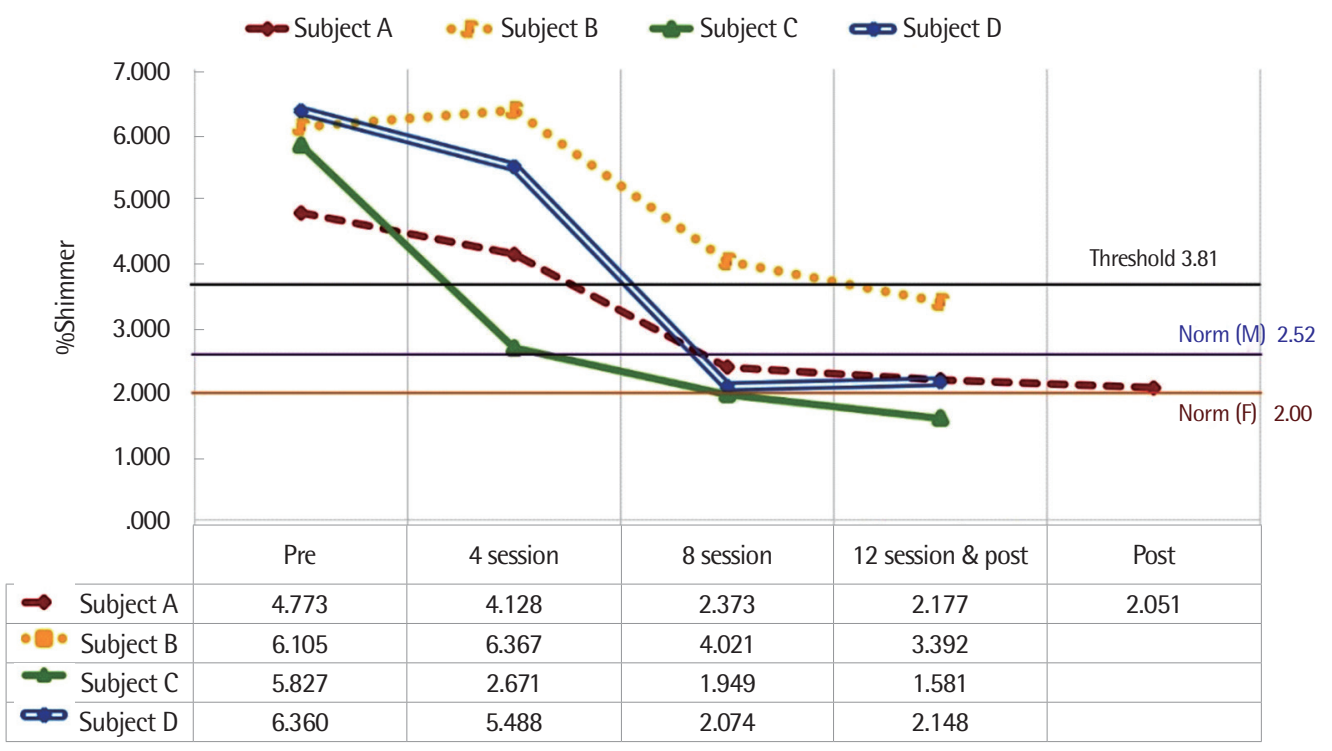

Figure 4. The acoustic parameter results (\%Shimmer).

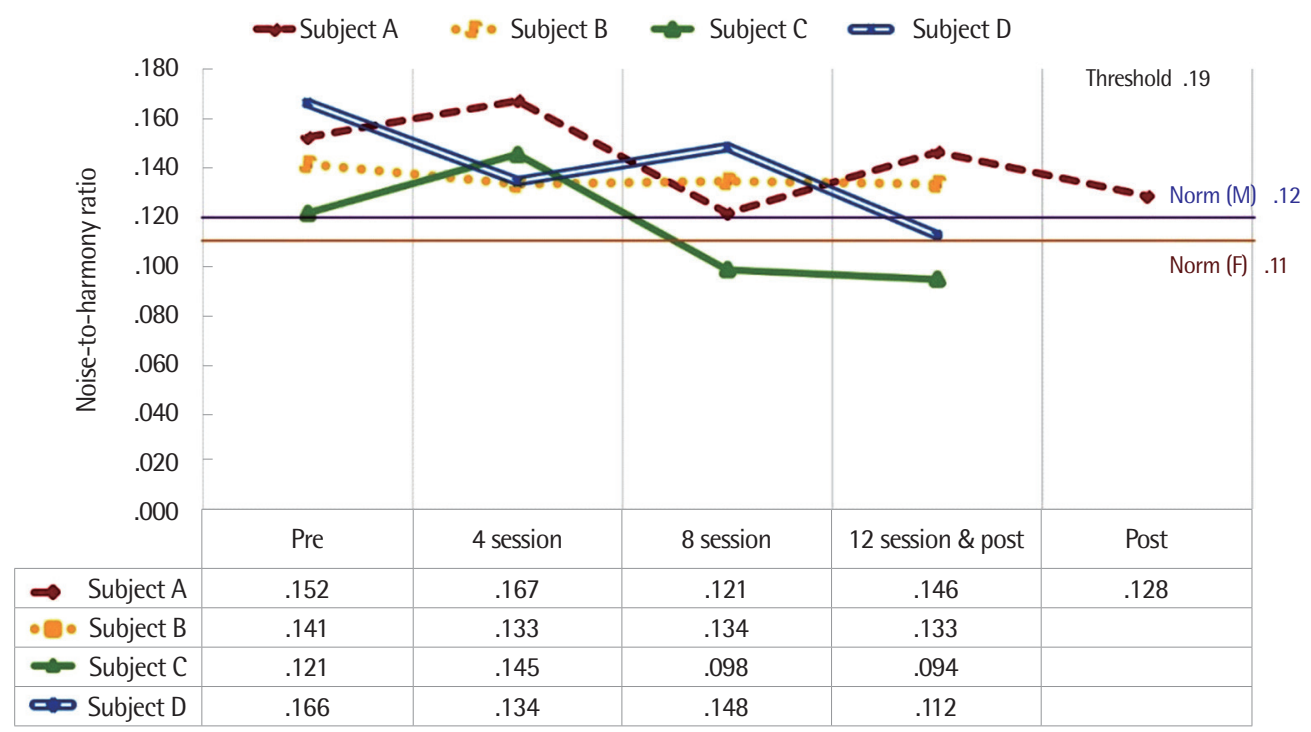

Figure 5. The acoustic parameter results (noise-to-harmony ratio). 
편안한 음도와 강도로 '산책' 문단의 세 문장과 '가을' 문단의 세 문 장을 읽도록 하였다. 각 문장을 1-2회 소리 내어 읽어본 뒤 녹음하 여 분석하였다.

대상자의 치료 전후 음역의 변화를 확인하기 위해 CSL의 voice range profile을 사용하였다. 과제 이해를 위해 모델링을 한 번 제공 하고 1 회 연습 후 녹음을 진행하였다. 최대 음도범위 $(\mathrm{Hz})$ 는 대상자 에게 편안한 음도와 강도로 모음 /a/를 반음씩 올려가면서 최대한 높은 음까지 산출하게 하고 반음씩 내려가면서 최대한 낮은 음도 까지 산출하도록 유도하였다. 총 3 회를 실시하여 가장 낮은 음도와 가장 높은 음도의 범위(pitch range)를 측정하였다.

\section{공기역학적 평가}

대상자의 치료 전후 공기역학적 평가를 위해 phonatory aerodynamic system (PAS, Model 6600; KayPENTAX)의 폐활량 프로토 콜을 사용하여 호기량(expiratory volume, FVC)을 측정하였고, 최 대 연장발성 프로토콜을 사용하여 발성시간(phonation time, $\mathrm{PHOT}$ ), 평균호기류율(mean expiratory airflow, MEAF)을 측정하 였다. 또한 음성효율 프로토콜을 사용하여 평균성문하압(mean peak air pressure, MPAP)을 측정하였다.

FVC는 폐활량을 알아보는 매개변수로 대상자에게 최대한 흡기 한 후 마스크를 얼굴에 밀착시킨 뒤 최대한 호기를 하도록 하였다. PHOT, MEAF는 대상자에게 최대한 흡기한 후 마스크를 얼굴에 밀착시킨 뒤 편안한 음도와 강도로 모음 /a/를 연장발성하도록 하 고, 3 회 반복 측정하여 최대값을 측정하였다. MPAP는 마스크를
얼굴에 밀착시킨 후 구강 내 튜브를 입술 사이에 위치시키고 /pa/를 초당 $1.5-2$ 음절의 속도로 5 번 반복하여 중간 3 회의 평균값을 측정 하였다(Figures 6,7).

\section{주관적 평가}

음성 만족도

대상자가 느끼는 음성상태를 신체적(physical, P), 기능적(functional, F), 정서적(emotional, E) 측면에서 알아보기 위해 한국어판 음성장애지수(Korean-Voice Handicap Index, K-VHI)를 사용하 였으며 이는 Jacobson 등(1997)이 고안한 음성장애지수(VHI)를 한국어로 번안하였다(Yun, Kim, Son, \& Choi, 2008). VHI는 세 가 지 하위 영역에 각각 10 문항씩 총 30 문항으로 평정척도는 5 점 척도 $(0=$ 전혀 그렇지 않다, $1=$ 거의 그렇지 않다, $3=$ 자주 그렇다, $4=$ 항 상 그렇다)로 구성되어 있다. 총 점수는 0 점에서 120 점까지이며 점 수가 높을수록 음성으로 인한 장애 정도가 높다고 평가된다(Jacobson et al., 1997). 점수에 따른 장애 정도는 VHI의 점수기준 표(Kandogan \& Sanal, 2005)를 참고하였으며 Table 2와 같다.

음성장애와 관련된 삶의 질과 치료의 호전도를 알아보기 위해 한국어판 음성과 관련된 삶의 질(Korean-Voice Related Quality of Life, K-VRQOL)을 사용하였으며 이는 Hogikyan과 Sethuraman (1999)이 고안한 V-RQOL을 한국어로 번안하였다(Kim et al., 2007). K-VRQOL은 10 항목으로 이루어져 있으며 이는 사회-심리(social emotional, SE), 신체 기능 영역(physical function, $\mathrm{PF}$ )으로 구성되 어 있다. 각 문항은 5 점 척도 $(1=$ 문제가 전혀 없다, $5=$ 문제가 더 이

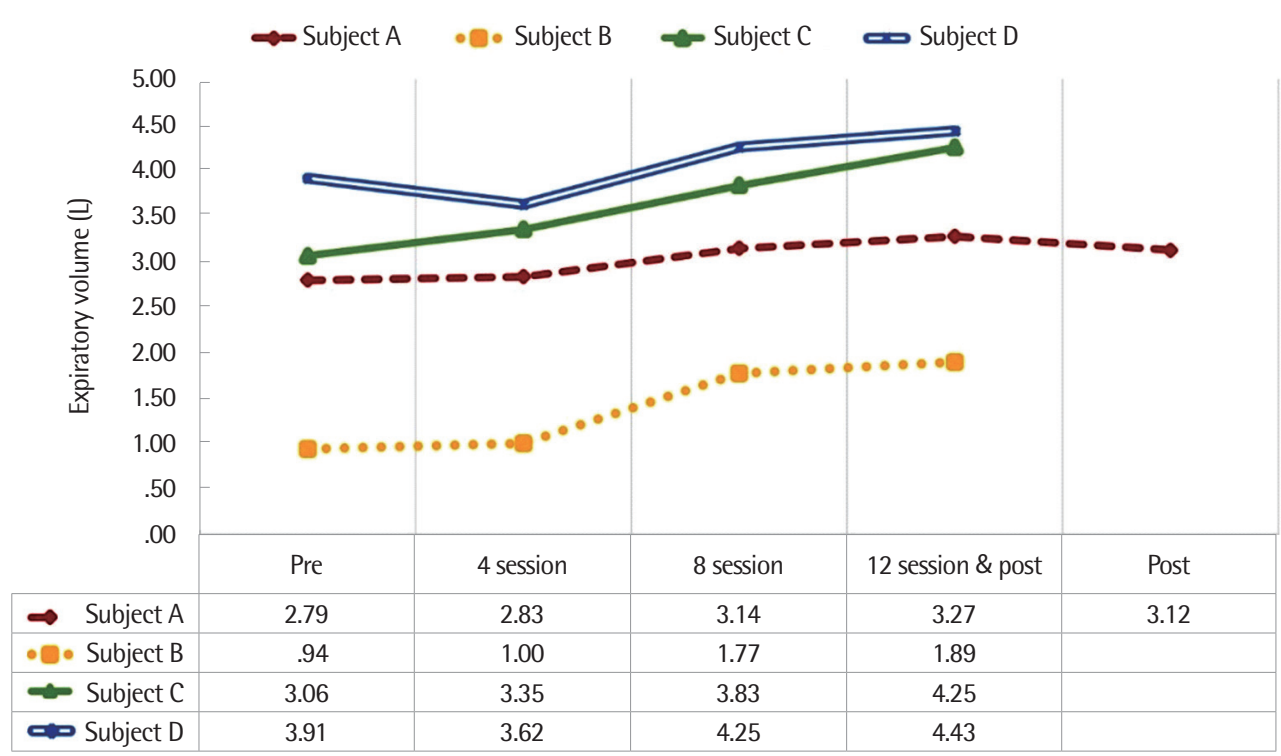

Figure 6. The aerodynamic parameter results (expiratory volume). 


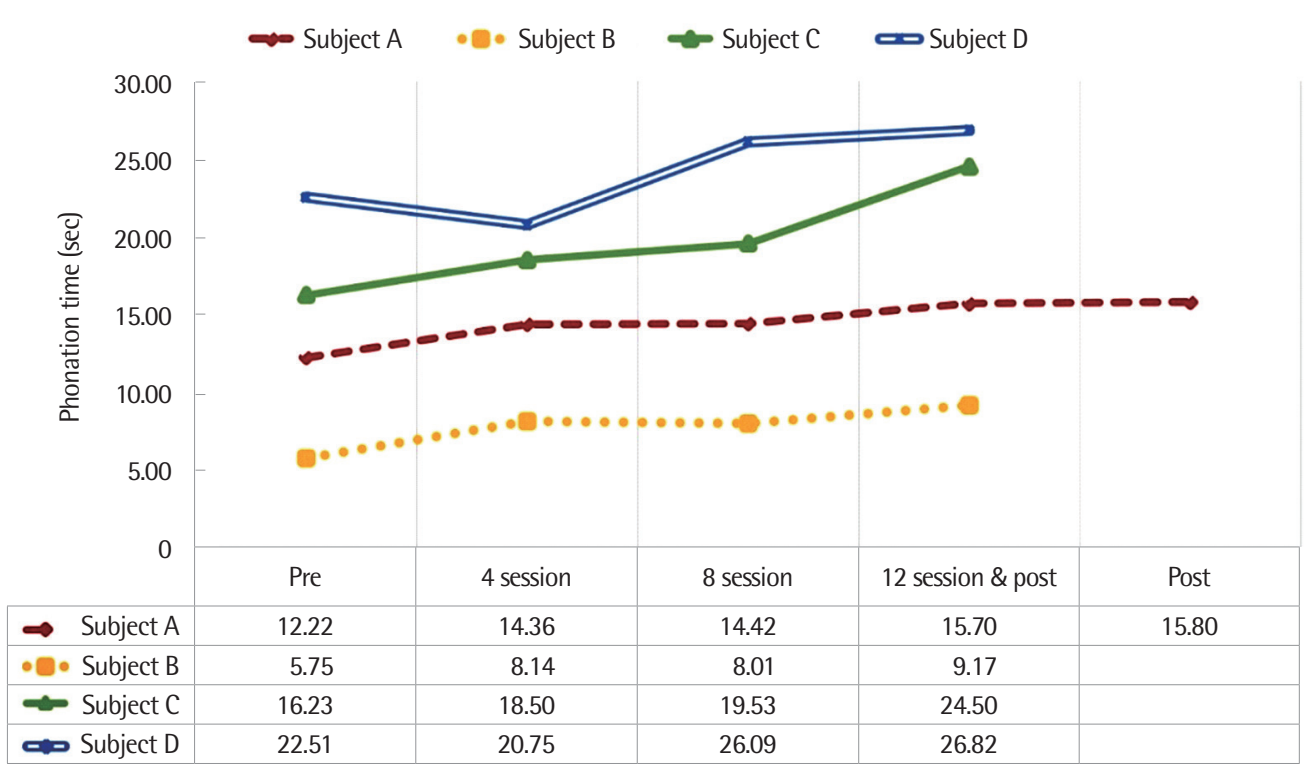

Figure 7. The aerodynamic parameter results (phonation time).

Table 2. The Voice Handicap Index (VHI) overall score

\begin{tabular}{ll}
\hline VHI score & \multicolumn{1}{c}{ Description } \\
\hline $0-30$ & This is a low score and indicates that there most likely is a minimal amount of handicap associate with voice disorder. \\
$31-60$ & Denotes a moderate amount of handicap due to the voice problem. \\
61-120 & This score represents a significant and serious amount of handicap due to a voice problem. \\
\hline
\end{tabular}

Table 3. The Voice Related Quality of Life (VROOL) overall score

\begin{tabular}{lc}
\hline VROOL score & VROOL standard score \\
\hline $10-15$ (excellent) & $87.5-100$ \\
$16-20$ (very good) & $75-85$ \\
$21-25$ (good) & $62.5-72.5$ \\
$26-30$ (fair) & $50-60$ \\
$30-50$ (poor) & $<50$ \\
\hline
\end{tabular}

상 나쁠 수 없을 만큼 심각하다)로 체크한다. 평가결과는 총 점수 및 세부 영역의 점수에 따라 0 점에서 100 점까지이며 0 점은 음성장 애로 인해 삶의 질이 가장 나쁜 것을 의미하고, 100 점은 음성장애가 삶의 질에 아무런 영향을 미치지 않는다는 것을 의미한다(Hogikyan \& Sethuraman, 1999). K-VRQOL의 점수기준은 Agarwal, Gogia, Agarwal, Agarwal과 Mathur (2015)의 연구의 V-RQOL의 점 수기준을 참고하였으며 Table 3과 같다.

\section{GRBAS scale}

GRBAS 척도는 임상가가 대상자의 음성을 듣고 평가하는 청지 각적 평가이다. G (grade)는 음성의 전반적인 목쉰 소리, R (roughness)은 거친 소리, B (breathiness)는 기식성 소리, A (asthenic)는
약한 소리, S (strained)는 쥐어짜는 소리를 말한다(Hirano, 1981). 본 연구의 GRBAS 척도 평가는 대상자가 '가을' 전체 문단을 읽는 것을 녹음한 후, 20 년 경력을 가진 1 급 언어재활사가 대상자의 음성 을 듣고 평정하였다.

\section{자료처리}

자료의 통계처리는 기술통계를 실시하였으며 호흡훈련기를 활 용한 VAT 프로그램을 통해 과기능적 음성장애인의 음성개선 정도 를 확인하고자 사전·중재·사후로 음향학적 매개변수 $\left(\mathrm{F}_{0}, \mathrm{SFF}, \%\right) \mathrm{it}-$ ter, \%Shimmer, NHR), 공기역학적 매개변수(FVC, PHOT, MEAF, $\mathrm{MPAP})$ 의 변화를 살펴보고 사전·사후로 음성 만족도, GRBAS scale 등을 측정하여 비교하였다.

\section{연구결과}

\section{음향학적 검사결과 비교}

연장발성 및 문단읽기 과제에 따른 음향학적 검사결과

음성치료 사전·중재·사후의 연장발성 및 문단읽기 과제에 따른 대상자별 검사결과는 Tables 4,5 와같다. 
Table 4. The acoustic parameters results of sustained phonation

\begin{tabular}{|c|c|c|c|c|c|c|}
\hline Subject & Parameter & Pre & 4 session & 8 session & 12 session & Post \\
\hline \multirow[t]{4}{*}{ A } & $\mathrm{F}_{0}(\mathrm{~Hz})$ & 221.011 & 229.093 & 217.842 & 207.176 & 216.094 \\
\hline & Jitter (\%) & 1.601 & 1.270 & 1.943 & 1.364 & .305 \\
\hline & Shimmer (\%) & 4.773 & 4.128 & 2.373 & 2.177 & 2.051 \\
\hline & $\mathrm{NHR}$ & .152 & .167 & .121 & .146 & .128 \\
\hline \multirow[t]{4}{*}{ B } & $\mathrm{F}_{0}(\mathrm{~Hz})$ & 213.692 & 222.061 & 225.056 & - & 236.796 \\
\hline & Jitter (\%) & 1.949 & 1.191 & 1.206 & - & 1.191 \\
\hline & Shimmer (\%) & 6.105 & 6.367 & 4.021 & - & 3.392 \\
\hline & $\mathrm{F}_{0}(\mathrm{~Hz})$ & .141 & .133 & .134 & - & .133 \\
\hline \multirow[t]{4}{*}{ C } & $\mathrm{F}_{0}(\mathrm{~Hz})$ & 202.424 & 236.267 & 270.831 & - & 287.212 \\
\hline & Jitter (\%) & 3.520 & 3.407 & .401 & - & .303 \\
\hline & Shimmer (\%) & 5.827 & 2.671 & 1.949 & - & 1.581 \\
\hline & $\mathrm{F}_{0}(\mathrm{~Hz})$ & .121 & .145 & .098 & - & .094 \\
\hline \multirow[t]{4}{*}{ D } & $\mathrm{F}_{0}(\mathrm{~Hz})$ & 139.212 & 131.390 & 152.025 & - & 154.471 \\
\hline & Jitter (\%) & 1.284 & 1.548 & .745 & - & .394 \\
\hline & Shimmer (\%) & 6.360 & 5.488 & 2.074 & - & 2.148 \\
\hline & $\mathrm{F}_{0}(\mathrm{~Hz})$ & .166 & .134 & .148 & - & .112 \\
\hline
\end{tabular}

NHR= noise-to-harmonic ratio.

Table 5. The acoustic parameter results of paragraph reading

\begin{tabular}{|c|c|c|c|c|c|c|c|}
\hline Subject & $\begin{array}{c}\text { Parame- } \\
\text { ter }\end{array}$ & Passage & Pre & $\begin{array}{c}4 \text { ses- } \\
\text { sion }\end{array}$ & $\begin{array}{c}8 \text { ses- } \\
\text { sion }\end{array}$ & $\begin{array}{c}12 \text { ses- } \\
\text { sion }\end{array}$ & Post \\
\hline \multirow[t]{2}{*}{ A } & $\mathrm{SFF}(\mathrm{Hz})$ & Gaeul & 181.42 & 199.45 & 189.95 & 190.50 & 200.38 \\
\hline & & Sanchaek & 177.26 & 193.75 & 192.90 & 198.54 & 198.70 \\
\hline \multirow[t]{2}{*}{ B } & $\mathrm{SFF}(\mathrm{Hz})$ & Gaeul & 195.95 & 202.96 & 200.49 & - & 206.74 \\
\hline & & Sanchaek & 191.29 & 193.13 & 195.38 & - & 210.23 \\
\hline \multirow[t]{2}{*}{ C } & $\mathrm{SFF}(\mathrm{Hz})$ & Gaeul & 187.28 & 235.35 & 244.92 & - & 248.12 \\
\hline & & Sanchaek & 192.32 & 234.51 & 240.37 & - & 253.22 \\
\hline \multirow[t]{2}{*}{ D } & $\mathrm{SFF}(\mathrm{Hz})$ & Gaeul & 134.54 & 141.58 & 138.11 & - & 141.87 \\
\hline & & Sanchaek & 133.87 & 139.53 & 143.09 & & 145.80 \\
\hline
\end{tabular}

$\mathrm{SFF}=$ speaking fundamental frequency.

대상자들의 $\mathrm{F}_{0}$ 변화를 살펴보면, 대상자 $\mathrm{B}, \mathrm{C}, \mathrm{D}$ 는 높아진 반면, 대상자 $\mathrm{A}$ 는 사전평가 $221.01 \mathrm{~Hz}$ 에서 사후평가 $216.09 \mathrm{~Hz}$ 로 낮아졌 다. \%jitter는 모든 대상자가 감소하였고 대상자 $\mathrm{B}$ 를 제외한 대상자 $\mathrm{A}, \mathrm{C}, \mathrm{D}$ 는 역치값(1.04\%) 안에 해당하였다. 성별에 따라 평균 정상 규준치를 비교하였을 때 대상자 $\mathrm{B}$ 는 여성 평균 정상규준치.63\%) 보다 높게 나타난 반면, 대상자 $\mathrm{A}, \mathrm{B}$ 가 여성 평균 정상규준치보다 낮게 나타났으며 대상자 D도 남성 평균 정상규준치(.59\%)보다 낮 게 나타났다. \%Shimmer는 모든 대상자가 감소하여 역치값(3.81\%)

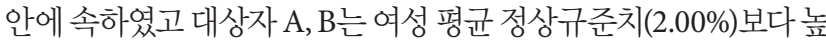
게 나타났으며 대상자 $\mathrm{C}, \mathrm{D}$ 는 여성 및 남성 평균 정상규준치 $(2.52 \%)$ 보다 낮게 나타났다. NHR은 모든 대상자가 사전평가부터 사후평 가까지 정상범위를 유지하였다.

문단읽기 과제에 따른 SFF의 변화를 살펴보면, '가을문단'과 '산
책문단'에서 모든 대상자의 음도가 높아진 것으로 나타났다.

\section{음성범위 프로파일 검사결과}

음성치료 사전·중재·사후의 대상자별 음역 검사결과는 Table 6 과같다.

대상자들의 음역을 살펴보면, 대상자 사전평가보다 사후평가에 서 모두 주파수 범위가 확장되었다. 반음 단위의 음역대는 대상자 $\mathrm{A}$ 를 제외한 나머지 대상자 $\mathrm{B}, \mathrm{C}, \mathrm{D}$ 는 반음 단위의 음역대가 증가하 였다.

\section{공기역학적 평가치 비교}

음성치료 사전·중재·사후의 대상자별 공기역학적 평가치는 $\mathrm{Ta}-$ ble 7과 같다.

대상자들의 공기역학적 평가치의 변화를 살펴보면, 대상자 $\mathrm{A}$ 와 $\mathrm{C}$ 는 $\mathrm{FVC}$ 가 증가하여 여성 $18-39$ 세의 정상수치인 $3.08 \mathrm{~L}$ 보다 높았 다. 대상자 D도 FVC가 증가하여 남성 18-39세의 정상수치인 $3.53 \mathrm{~L}$ 보다 높았던 반면, 대상자 B는 FVC가 증가하였지만 여성 40-59세 의 정상수치인 $3.01 \mathrm{~L}$ 보다는 낮았다. $\mathrm{PHOT}$ 는 모든 대상자가 길어 겼으나 대상자 $\mathrm{A}, \mathrm{B}$ 는 여성 18-39세의 정상수치인 22.00초와 여성 40-59세의 정상수치인 21.24초보다는 짧았으며 대상자 C, $\mathrm{D}$ 는 여 성 18-39세의 정상수치와 남성 18-39세의 정상수치인 21.89초보다 더 길었다. MEAF는 모든 대상자가 사전평가부터 사후평가까지 정 상수치에 해당하였고 MPAP는 모든 대상자가 사전평가에 비해 사 후평가에서 낮아졌다. 전반적으로 대상자들은 폐활량이 증가하고 
Table 6. Results of subjects' pitch range

\begin{tabular}{|c|c|c|c|c|c|c|}
\hline Subject & Parameter & Pre & 4 session & 8 session & 12 session & Post \\
\hline \multirow{4}{*}{ A } & Maximum $\mathrm{F}_{0}(\mathrm{~Hz})$ & 415.30 & 392.00 & 415.30 & 440.00 & 440.00 \\
\hline & Minimum $\mathrm{F}_{0}(\mathrm{~Hz})$ & 146.83 & 138.59 & 146.83 & 155.56 & 155.56 \\
\hline & Pitch range $(\mathrm{Hz})$ & 268.47 & 253.41 & 268.47 & 284.44 & 284.44 \\
\hline & Pitch range (semitone) & 18 & 18 & 18 & 18 & 18 \\
\hline \multirow[t]{4}{*}{ B } & Maximum $\mathrm{F}_{0}(\mathrm{~Hz})$ & 392.00 & 392.00 & 415.30 & - & 415.30 \\
\hline & Minimum $F_{0}(\mathrm{~Hz})$ & 185.00 & 174.61 & 185.00 & - & 185.00 \\
\hline & Pitch range (Hz) & 207.00 & 217.39 & 230.30 & - & 230.30 \\
\hline & Pitch range (semitone) & 13 & 14 & 14 & - & 14 \\
\hline \multirow[t]{4}{*}{ C } & Maximum $\mathrm{F}_{0}(\mathrm{~Hz})$ & 783.99 & 830.61 & 880.00 & - & 932.33 \\
\hline & Minimum $\mathrm{F}_{0}(\mathrm{~Hz})$ & 196.00 & 155.56 & 155.56 & - & 130.81 \\
\hline & Pitch range (Hz) & 587.99 & 675.05 & 724.44 & - & 801.52 \\
\hline & Pitch range (semitone) & 24 & 29 & 30 & - & 34 \\
\hline \multirow[t]{4}{*}{ D } & Maximum $\mathrm{F}_{0}(\mathrm{~Hz})$ & 329.63 & 349.23 & 392.00 & - & 415.30 \\
\hline & Minimum $F_{0}(\mathrm{~Hz})$ & 92.50 & 103.83 & 116.54 & - & 103.83 \\
\hline & Pitch range $(\mathrm{Hz})$ & 237.13 & 245.40 & 275.46 & - & 311.47 \\
\hline & Pitch range (semitone) & 22 & 21 & 21 & - & 24 \\
\hline
\end{tabular}

Table 7. Aerodynamic parameter results of subjects

\begin{tabular}{|c|c|c|c|c|c|c|}
\hline Subject & Parameter & Pre & 4 session & 8 session & 12 session & Post \\
\hline \multirow[t]{4}{*}{ A } & FVC (L) & 2.79 & 2.83 & 3.14 & 3.27 & 3.12 \\
\hline & PHOT (sec) & 12.22 & 14.36 & 14.42 & 15.70 & 15.80 \\
\hline & MEAF (L/sec) & .14 & .12 & .13 & .15 & .15 \\
\hline & $\mathrm{MPAP}\left(\mathrm{cmH}_{2} \mathrm{O}\right)$ & 9.96 & 10.82 & 9.43 & 8.48 & 7.57 \\
\hline \multirow[t]{4}{*}{ B } & $\mathrm{FVC} \mathrm{(L)}$ & .94 & 1.00 & 1.77 & - & 1.89 \\
\hline & PHOT (sec) & 5.75 & 8.14 & 8.01 & - & 9.17 \\
\hline & MEAF (L/sec) & .22 & .20 & .11 & - & .12 \\
\hline & MPAP ( $\left.\mathrm{cmH}_{2} \mathrm{O}\right)$ & 15.04 & 20.67 & 19.88 & - & 13.50 \\
\hline \multirow[t]{4}{*}{ C } & $\mathrm{FVC}(\mathrm{L})$ & 3.06 & 3.35 & 3.83 & - & 4.25 \\
\hline & РHOT (sec) & 16.23 & 18.50 & 19.53 & - & 24.50 \\
\hline & MEAF (L/sec) & .11 & .11 & .10 & - & .09 \\
\hline & MPAP $\left(\mathrm{cmH}_{2} \mathrm{O}\right)$ & 15.15 & 12.17 & 15.37 & - & 13.84 \\
\hline \multirow[t]{4}{*}{ D } & FVC (L) & 3.91 & 3.62 & 4.25 & - & 4.43 \\
\hline & PHOT (sec) & 22.51 & 20.75 & 26.09 & - & 26.82 \\
\hline & MEAF (L/sec) & .17 & .15 & .14 & - & .16 \\
\hline & MPAP $\left(\mathrm{cmH}_{2} \mathrm{O}\right)$ & 10.09 & 10.24 & 9.35 & - & 9.85 \\
\hline
\end{tabular}

$\mathrm{FVC}=$ expiratory volume; $\mathrm{PHOT}$ = phonation time; $\mathrm{MEAF}=$ mean expiratory airflow; $\mathrm{MPAP}=$ mean peak air pressure.

연장발성시간이 길어져 호흡능력이 향상되었다.

\section{주관적 평가결과 비교}

\section{음성 설문}

음성장애지수

음성치료 사전·사후 대상자별 음성장애지수 결과는 Table 8에 제시하였다.
Table 8. The Voice Handicap Index (VHI) scores of subjects

\begin{tabular}{|c|c|c|c|c|c|c|c|c|}
\hline \multirow{3}{*}{ Subject } & \multicolumn{8}{|c|}{ VHI score } \\
\hline & \multicolumn{2}{|c|}{ Functional } & \multicolumn{2}{|c|}{ Physical } & \multicolumn{2}{|c|}{ Emotional } & \multicolumn{2}{|c|}{ Total } \\
\hline & Pre & Post & Pre & Post & Pre & Post & Pre & Post \\
\hline A & 4 & 2 & 19 & 7 & 0 & 0 & 23 & 9 \\
\hline B & 18 & 8 & 18 & 9 & 12 & 4 & 48 & 21 \\
\hline C & 10 & 2 & 22 & 6 & 16 & 0 & 48 & 8 \\
\hline D & 19 & 13 & 24 & 16 & 21 & 6 & 64 & 35 \\
\hline
\end{tabular}

대상자 $\mathrm{A}$ 는 사전평가에서 본인의 음성문제에 대해 신체적으로 가장 많은 어려움을 보였으며 총점은 23점으로 중증도는 '경미'에 해당하였다. 사후평가에서는 음성문제의 어려움이 신체적 영역에 서 가장 많이 감소하였고 총점은 9점으로 감소하였으며 중증도는 '경미'에 해당하였다.

대상자 $\mathrm{B}$ 는 사전평가에서 본인의 음성문제에 대해 기능적 및 신 체적으로 가장 많은 어려움을 보였고 감정적으로도 불편감이 있었 다. 총점은 48 점으로 중증도는 ‘중등도'에 해당하였다. 사후평가에 서는 음성문제의 어려움이 기능적 및 신체적 영역에서 많이 감소하 였고 감정적 영역도 감소하였다. 총점은 21점으로 나타났으며 중증 도는 '경미'에 해당하였다.

대상자 $\mathrm{C}$ 는 사전평가에서 본인의 음성문제에 대해 신체적으로 가장 많은 어려움을 보였으며 기능적 및 감정적으로도 어려움을 보 였다. 사후평가에서는 음성문제의 어려움이 신체적 영역에서 가장 많이 감소하였고 기능적 및 감정적 영역에서도 많이 감소하였다. 총 점은 8 점으로 중증도는 '경미'에 해당하였다. 
대상자 $\mathrm{D}$ 는 사전평가에서 본인의 음성문제에 대해 전반적으로 어려움을 보였고 이 중에서도 신체적으로 가장 많은 음성문제의 어려움을 가졌다. 총점은 64점으로 중증도는 '심도'에 해당하였다. 사후평가에서는 음성문제의 어려움이 전반적으로 감소하였으며 특히 감정적으로 음성문제에 대한 불편감은 많이 낮아졌다. 총점 은 35점으로 중증도는 '중등도'에 해당하였다.

\section{음성관련 삶의 질}

음성치료 사전·사후의 대상자별 음성관련 삶의 질 결과는 Table

Table 9. The Korean-Voice Related Quality of Life (K-VROOL) standard scores of subjects

\begin{tabular}{|c|c|c|c|c|c|c|c|c|}
\hline \multirow{3}{*}{ Subject } & \multicolumn{8}{|c|}{ K-VROOL standard score } \\
\hline & \multicolumn{2}{|c|}{$\begin{array}{c}\text { Social- } \\
\text { emotional }\end{array}$} & \multicolumn{2}{|c|}{$\begin{array}{l}\text { Physical } \\
\text { functioning }\end{array}$} & \multicolumn{2}{|c|}{ Total } & \multicolumn{2}{|c|}{$\begin{array}{l}\text { Voice } \\
\text { quality }\end{array}$} \\
\hline & Pre & Post & Pre & Post & Pre & Post & Pre & Post \\
\hline A & 100 & 100 & 79.17 & 100 & 87.5 & 100 & Poor & Good \\
\hline B & 75 & 87.5 & 48.83 & 83.33 & 57.5 & 85 & Poor & Fair \\
\hline C & 75 & 100 & 58.3 & 95 & 65 & 95 & Fair & Excellent \\
\hline D & 68.75 & 100 & 41.67 & 95 & 52.5 & 95 & Poor & Fair \\
\hline
\end{tabular}
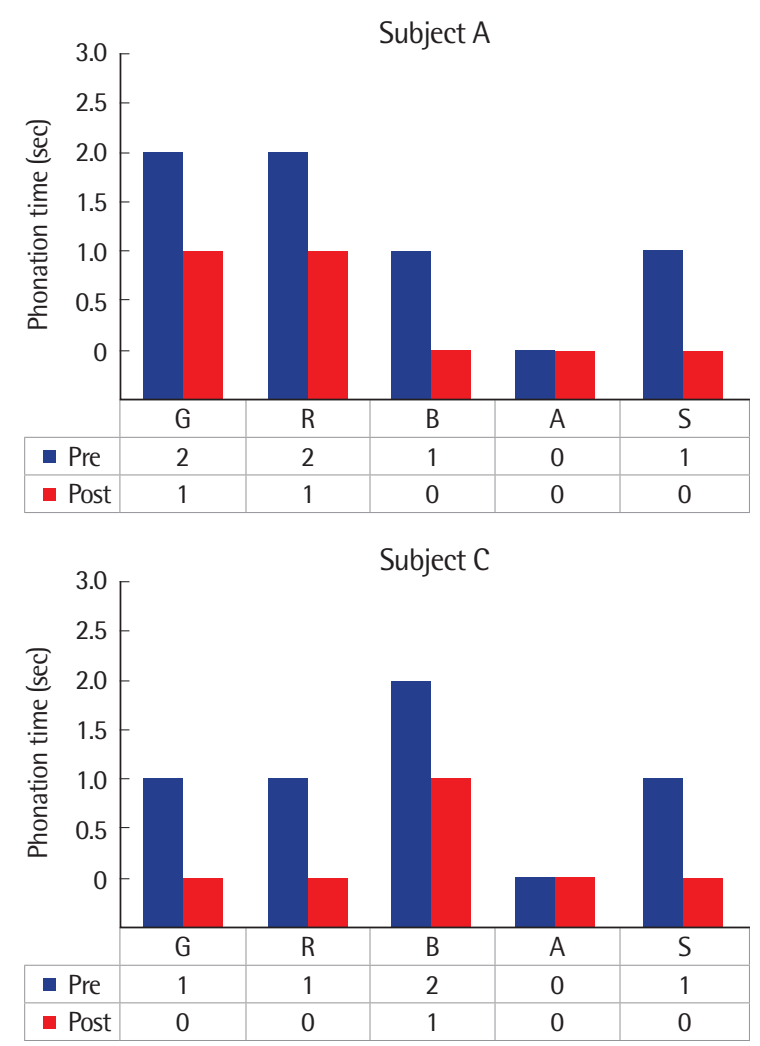

9에 제시하였다.

대상자 $\mathrm{A}$ 는 사전평가에서 음성과 관련하여 신체기능 영역에서 약간 낮은 삶의 질을 보였지만 총점은 87.5점으로 전체적인 음성관 련 삶의 질은 '훌륭함(excellent)'에 해당하였다. 사후평가에서는 모 든 영역에서 음성관련 삶의 질이 높아졌으며 총점은 100 점으로 전 체적인 음성관련 삶의 질은 ‘훌륭함(excellent)'에 해당하였다. 또한 ‘당신의 음성의 질을 평가한다면 어떠합니까?'의 기타문항에서는 사전평가의 ‘나쁨'이 치료 후 ‘좋음’으로 바뀌어 음성의 만족도가 향상되었다.

대상자 $\mathrm{B}$ 는 사전평가에서 음성과 관련하여 신체기능 영역이 가 장 낮은 삶의 질을 보였고 사회-심리 영역에서도 약간 낮은 삶의 질 을 보였다. 총점은 57.5점으로 전체적인 음성관련 삶의 질은 '적당 함(fair)'에 해당하였다. 사후평가에서는 신체기능 영역에서 음성관 련 삶의 질이 가장 많이 높아졌고 사회-심리 영역에서도 약간 높아 졌다. 또한 기타문항에서는 사전평가의 ‘나쁨'이 치료 후 ‘적당함’으 로 바뀌어 음성의 만족도가향상되었다.

대상자 $\mathrm{C}$ 는 사전평가에서 음성과 관련하여 신체기능 영역에서 낮은 삶의 질을 보였고 사회-심리 영역에서도 약간 낮은 삶의 질을 보였다. 총점은 65 점으로 전체적인 음성관련 삶의 질은 '적당함
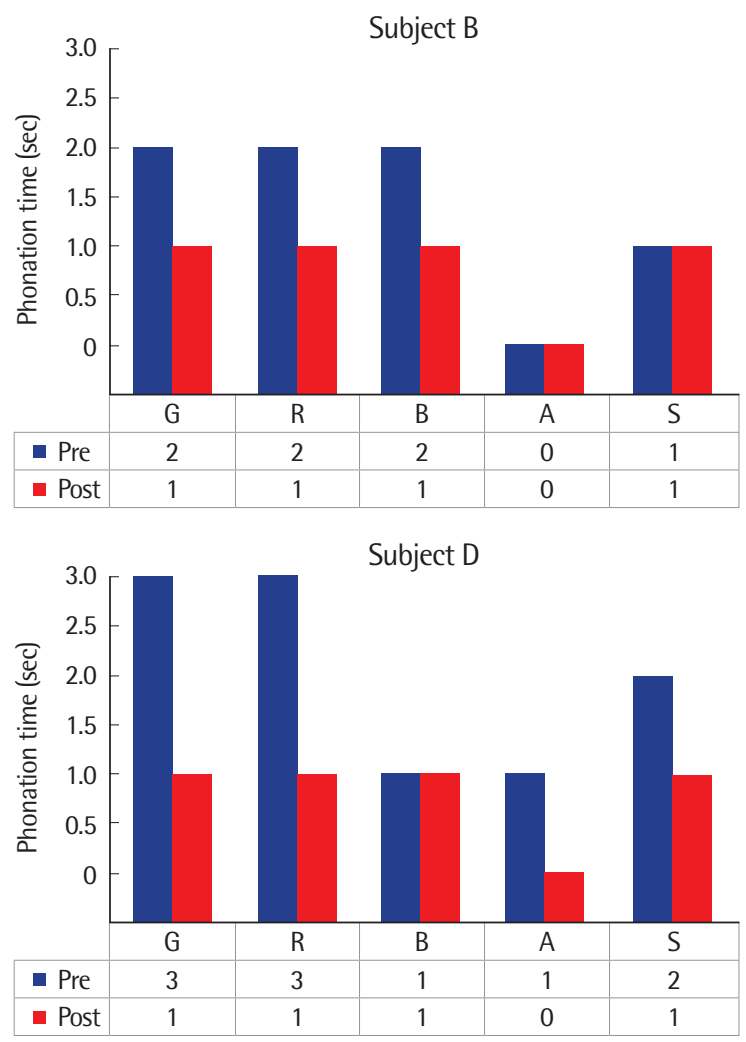

Figure 8. The GRBAS scale score of subjects. 
(Fair)'에 해당하였다. 사후평가에서는 모든 영역에서 음성관련 삶 의 질이 높아졌으며 총점은 95점으로 전체적인 음성관련 삶의 질 은 ‘훌륭함(excellent)'에 해당하였다. 또한 기타문항에서는 사전평 가의 '적당함'이 치료 후 ‘훌륭함'으로 바뀌어 음성의 만족도가 향 상되었다.

대상자 $\mathrm{D}$ 는 사전평가에서 음성과 관련하여 모든 영역에서 낮은 삶의 질을 보였으며 총점은 52.5점으로 전체적인 음성관련 삶의 질 은 '나쁨(poor)'에 해당하였다. 사후평가에서는 모든 영역에서 음 성관련 삶의 질이 높아졌으며 총점은 95점으로 전체적인 음성관련 삶의 질은 '훌륭함(excellent)'에 해당하였다. 또한 기타문항에서는 사전평가의 ‘나쁨’이 치료 후 ‘적당함’으로 바뀌어 음성의 만족도가 향상되었다.

\section{GRBAS scale}

음성치료 사전·사후의 대상자별 GRBAS scale 결과는 Figure 8 과같다.

호흡훈련기를 활용한 VAT 프로그램이 음성개선에 미치는 영향 을 GRBAS 척도로 알아본 결과, 치료 후 대상자 모두 목쉰 소리(G) 와 거친 소리(R)가 크게 개선되었으며 대상자별로 기식성 소리(B), 쥐어짜는 소리(S)도 개선되었다. 전반적으로 대상자들은 치료 전보 다치료 후에 더 편안하고 부드러운 음성을 산출하였다.

\section{논의 및 결론}

본 연구는 호흡훈련기를 활용한 VAT 프로그램을 과기능적 음 성장애인에게 적용하여 음성개선의 효과를 밝히고자 하였다. 대상 자별로 VAT 프로그램 적용 사전·중재·사후의 음향학적 및 공기역 학적 매개변수의 변화를 살펴보고, 사전·사후로 자가보고 음성설 문과 GRBAS 척도를 실시하여 음성개선 정도를 알아보았다. 연구 결과는 다음과 같았다.

첫째, 호흡훈련기를 활용한 VAT 프로그램을 적용하여 음도와 발화음도의 변화를 살펴본 결과, 대상자들의 음도, 발화음도가 전 반적으로 상승하였다. 이 결과는 가수들에게 LaxVox를 실시한 후 음도가 증가했다는 연구(Fadel et al., 2016)와 음성장애 여성교사 에게 공명음성치료를 실시한 후 발화기본주파수가 높아졌다는 연 구(Chen, Hsiao, Hsiao, Chung, \& Chiang, 2007)와 일치하였다. 중 재 전 음도가 전반적으로 낮았던 것은 대상자들이 음성을 많이 사 용하는 직업적 음성사용자로 후두 근육이 피로하여 성대 조직을 변화시켰고 이로 인한 성대병변으로 낮은 음도가 나타난 것으로 생 각된다. 따라서 중재기간 동안 대상자들의 성대병변이 호전되면서
낮은 음도가 상승된 것으로 보인다. 또한 대상자 $\mathrm{B}$ 와 $\mathrm{D}$ 는 직업적으 로 더 좋은 목소리를 내기 위해 인위적으로 음도를 낮게 사용하였 는데 중재기간 동안에 대상들에게 적절한 음도로 조정하여 발화 하는 활동으로 음도가 높아진 것으로 보인다. 반면, 대상자 $\mathrm{A}$ 의 경 우 중재기간에 음도가 $207.18 \mathrm{~Hz}$ 로 낮아진 모습을 보였는데 이는 대상자의 감기 및 호르몬 등 건강상태가 음성에 약간 영향을 준 것 으로 보인다.

둘째, 호흡훈련기를 활용한 VAT 프로그램을 적용하여 음향학 적 평가를 실시한 결과, 대상자들의 음향학적 매개변수(\%)itter, $\%$ Shimmer, NHR)의 수치가 감소하여 음질이 개선되었다. 이 결과 는 소프라노 성악가에게 VAT 프로그램을 실시한 후 음향학적 매 개변수가 감소하였다는 연구(Yoo \& Lee, 2018)와 일치하였다. 또한 직업적 음성사용자에게 총체적 음성관리 프로그램을 실시한 $\operatorname{Han}$ 과 Jeong (2002)의 선행연구에서도 치료 후 음질과 관련된 음향학 적 매개변수 값이 감소하였다. 이는 호흡, 공명, 발성을 전반적으로 다루는 총체적 음성치료인 VAT 프로그램이 호흡 및 발성을 변화시 켜 보다음성을 부드럽게 산출하는 데 효과적인 것을 알 수 있다. 이 외에도 근긴장 음성장애 교사에게 성대기능훈련을 실시한 Nguyen과 Kenny (2009)의 연구와 성대결절 환자를 대상으로 복식호흡 훈련 프로그램과 self voice feedback 프로그램을 활용한 음성치료 를 시행한 Kwon, Wang, Yang과 Jeon (2006)의 연구에서도 치료 후 본 연구와 같이 음질과 관련된 음향학적 매개변수 값이 감소하였 다. 앞에 제시한 선행연구를 살펴보면, 총체적 음성치료와 호흡훈 련이 직업적 음성사용자, 일반 성인, 음성장애인 등 여러 대상자의 음성개선에 유용하여 호흡훈련기를 활용한 VAT 프로그램도 음성 치료 분야에서 긍정적인 효과를 줄 수 있는 치료법으로 사용할 수 있다는 것을 알 수 있다.

셋째, 호흡훈련기를 활용한 VAT 프로그램을 적용하여 음역평 가를 실시한 결과, 대상자들의 음역대가 넓어졌으며 반음 단위의 음역대도 증가하였다. 본 결과는 소프라노 성악에게 VAT를 적용한 후음역의 범위가 넓어졌다는 연구(Yoo \& Lee, 2018)와 일치하였고, 건강한 가수에게 노래연습과 성대기능훈련을 실시한 Sabol, Lee와 Stemple (1995) 연구에서도 최대음도 범위가 확장된 것으로 나타났 다. 대상자들은 호흡훈련기를 활용한 VAT 프로그램 적용 후 전보 다 높은 음을 산출하여 음역대가 전반적으로 확장되었으며 이는 VAT 프로그램이 음성장애인의 음역대를 확장시키는 데 유용하다 는 것을 보여준다.

넷째, 호흡훈련기를 활용한 VAT 프로그램을 적용하여 공기역학 적 평가를 실시한 결과, 대상자들의 공기역학적 매개변수인 FVC, $\mathrm{PHOT}$ 의 향상으로 폐활량과 최대연장발성시간이 증가하고 $\mathrm{MEAF}$ 
와 MPAP의 개선으로 평균호기류율과 성문하압이 향상되었다. 이 는 노래연습과 성대기능훈련을 가수 집단에게 실시하여 발성공기 량과 MFR, MPT가 개선되었다는 연구(Sabol et al., 1995)와 일치하 였다. 본 연구와 호흡훈련 프로그램 및 호흡훈련기를 사용한 선행 연구를 함께 살펴봤을 때, 연구결과는 전반적으로 호흡능력이 향 상되어 음성기능이 개선되었다는 경향성이 있었다. 복식호흡과 발 성훈련을 실시한 Moon, Chung, Kim과 Kim (1999)은 MFR, MPT 등이 증가되었다고 보고하였고 음성장애인에게 EMST를 사용하 여 음성치료를 실시한 Wingate 등(2007)과 Tsai 등(2016)의 연구에 서도 $\mathrm{MEP}$ 를 증가시켜 음성기능이 향상된 것으로 나타났다. 또한 Wingate 등(2007)은 단일치료보다 전통적인 음성치료와 호흡근 력 강화훈련을 함께 실시하는 것이 음성개선에 효과적이라고 하였 다. 이는 호흡훈련기를 같이 접목시킨 VAT 프로그램이 호흡능력 을 개선시키는 데 효과적임을 뒷받침해 준다.

다만, 본 연구의 MPAP를 살펴보면, 모든 대상자가 사전평가보다 사후평가에서 낮아졌으나 대상자 $\mathrm{B}$ 와 $\mathrm{C}$ 는 $10 \mathrm{cmH}_{2} \mathrm{O}$ 보다 약간 높 게 측정된 것을 볼 수 있다. 하지만 치료 초기에 비해서는 성문하압 이 다소 정상범주 쪽으로 낮아지는 긍정적인 결과를 나타내었다. 일반적으로 5-10 $\mathrm{cmH}_{2} \mathrm{O}$ 가 말을 산출하는 데 필요한 성문하압이 라고 볼 때, $10 \mathrm{cmH}_{2} \mathrm{O}$ 보다 약간 높게 측정된 것은 대상자마다 수 행하는 수준 및 음성장애 정도, 연습 등의 영향과 증가한 폐활량으 로 발성시 좀 더 강한 호기압을 사용함으로써 성문하압이 약간 높 게 나타났을 것으로 판단된다.

다섯째, 호흡훈련기를 활용한 VAT 프로그램을 적용하여 음성 설문지를 실시한 결과, $\mathrm{VHI}$ 값이 감소하고 $\mathrm{K}-\mathrm{VRQOL}$ 값이 높아짐 으로써 대상자들의 음성만족도가 향상되었다. 이는 음성장애 교 사에게 VFE를 적용한 Roy 등(2001)의 연구와 성대결절 환자들에 게 VFE를 실시한 Lim, Kim, Kwon과 Park (2009)의 연구에서도 $\mathrm{VHI}$ 가 감소한 것으로 나타나 본 연구결과와 일치하였다. 본 연구 에서는 Kandogan과 Sanal (2005)과 Agarwal 등(2015)의 VHI와 $\mathrm{V}-\mathrm{RQOL}$ 의 점수기준을 참고하여 장애 정도를 알아봤으나 서로 다 른 언어문화권의 기준점수로 장애 정도를 판단하기에는 어려움이 있다. 추후에 한국어 문화권의 점수기준을 만들어 적용한다면 장 애 정도를 정확하게 판단하는 데 도움이 될 것이다. 또한 소프라노 성악가에게 VAT 프로그램을 적용한 Yoo와 Lee (2018)는 '당신의 목소리는 얼마나 심각한가요?'의 기타항목에서 치료 전 '심각함’이 '경미함'으로 체크되어 음성만족도가 향상된 것으로 보고하였다. 본 연구에서도 '당신의 음성의 질을 평가한다면 어떠합니까?'라는 기타항목에서 치료 전 ‘나쁨'을 치료 후 ‘적당함’ 또는 ‘좋음' 등으로 체크하여 전반적인 음성의 만족도가 향상된 것으로 나타났다.
마지막으로, 호흡훈련기를 활용한 VAT 프로그램을 적용하여 GRBAS 척도를 실시한 결과, 목쉰 소리 $(\mathrm{G})$, 거친 소리(R), 기식성 소 리(B) 등에서 전반적으로 청지각적으로 음성이 개선되었다. 이는 과기능적 음성장애 환자에게 후두마사지와 반폐쇄 성도훈련을 실 시한 Kim, Lee, Choi와 Choi (2017)의 연구와 일치하였다. 본 프로 그램은 대상자들의 음성을 좀 더 편안하고 부드러운 음성을 산출 하도록 음성을 개선시키는 데 유용하다는 것을 보여준다.

본 연구는 호흡훈련기를 활용한 VAT 프로그램의 음성개선 효 과를 검증하기 위한 사례연구로 과기능적 음성장애인에게 적용했 을 때 음도, 음질, 음역, 호흡 등의 개선과 음성 만족도 향상에 효과 적인 것으로 나타났다. 이는 호흡훈련기를 활용한 VAT 프로그램 이 총체적 음성치료법으로 음성산출의 필요한 호흡, 공명, 발성 등 을 종합적으로 다뤄 음성장애인에게 효과적이었다고 할 수 있다. 또한 본 프로그램은 신체움직임과 허밍 등을 이용하여 호흡훈련을 실시한 기존의 VAT 프로그램에 비해 호흡훈련기를 사용함으로써 대상자들에게 호기압과 부는 느낌의 피드백을 제공하여 호기압의 정도를 확인할 수 있다는 점을 활용하였다. 호흡훈련기를 이용하 여 다양한 호기압력을 유지하면서 부는 활동을 통해 일정한 공기 압력을 조절하고 유지하는 기능을 향상시키고자 하였고 대상자가 호기압력의 정도를 점검하여 발성 및 발화단계에서 너무 강한 성대 접촉과 후두의 과긴장이 발생하지 않는 적절한 호기압을 유지할 수 있도록 훈련하였다. 따라서 본 연구는 국내에서 호흡훈련기를 활용한 음성치료가 많이 이루어지지 않은 점을 고려할 때, 음성치 료분야에서 유용하게 사용될 수 있는 음성치료 프로그램을 제시 하였다는 점에서 연구의 의의가 있다.

본 연구에서 밝혀진 결과들을 바탕으로 본 연구의 제한점과 앞 으로의 후속연구를 위한 제언은 다음과 같다.

첫째, 본 연구는 대상자 4 명에게 호흡훈련기를 활용한 VAT 프로 그램을 적용하여 음성개선을 알아보았다. 하지만 실험대상자 수가 적었기 때문에 이 연구결과를 일반화하는 데 제한이 있다. 따라서 보다 많은 대상자를 선정하여 다양한 직업군을 대상으로 후속연구 가이루어질 필요가 있다.

둘째, 본 연구는 과기능적 음성장애를 대상으로 한 사례연구로 음성장애 세부 유형을 분류하지 않고 각 대상자의 음성변화를 살 펴보았다. 차후에는 다양한 유형의 음성장애인을 대상으로 음성장 애 유형별, 음성장애 심한 정도에 따른 비교 연구가 이루어진다면 본 프로그램에 대해 더 많은 정보를 제공할 수 있을 것이다.

셋째, 본 연구는 대상자마다 음성장애 정도가 상이하여 회기 수 를 다르게 진행하였다. 후속연구로 치료 회기 수를 통일하고 사전. 중재·사후평가 이후 유지평가도 같이 진행하여 치료 회기에 따른 
음성개선 정도를 살펴본다면 더 의미 있는 연구가 될 것이다.

넷째, 본 연구는 호흡훈련기로 Threshold PEP와 EMST를 같이 사용하였고 Threshold PEP는 5-20 $\mathrm{cmH}_{2} \mathrm{O}$ 의 호기압으로 호흡 및 발성훈련에 적용하였고 EMST는 발성 시에 필요한 호기압보다 높 은 30-45 $\mathrm{cmH}_{2} \mathrm{O}$ 의 호기압으로 호흡훈련에 적용하여 VAT 프로그 램을 실시하였다. 하지만 어떤 호흡훈련기가 더 유용한지, 호흡훈 련기로 음성개선이 나타났는지 알아보는 데 어려운 점이 있다. 따 라서 호흡훈련기의 활용여부 및 종류에 따른 VAT 프로그램 적용 효과의 후속연구가 이루어질 필요가 있다.

마지막으로, 본 연구는 대상자들이 가정에서 연습할 수 있는 관 리 프로그램이 부족하였다. 차후에는 임상에서 실시하는 음성치료 뿐만 아니라 대상자들이 가정연습 프로그램을 같이 제공한다면 더 긍정적인 효과가 나타날 것으로 생각된다.

\section{REFERENCES}

Agarwal, S. K., Gogia, S., Agarwal, A., Agarwal, R., \& Mathur, A. S. (2015). Assessment of voice related quality of life and its correlation with socioeconomic status after total laryngectomy. Annals of Palliative Medicine, 4(4), 169-175.

Aspire. (2018). EMST150 how it works. https://emst150.com/how-it-works/. Chen, S. H., Hsiao, T. Y., Hsiao, L. C., Chung, Y. M., \& Chiang, S. C. (2007). Outcome of resonant voice therapy for female teachers with voice disorders: perceptual, physiological, acoustic, aerodynamic, and functional measurements. Journal of Voice, 21(4), 415-425.

Darling-White, M., \& Huber, J. E. (2017). The impact of expiratory muscle strength training on speech breathing in individuals with Parkinson's disease: a preliminary study. American Journal of Speech-Language Pathology, 26(4), 1159-1166.

Fadel, C. B. X., Dassie-Leite, A. P., Santos, R. S., Santos Junior, C. G. D., Dias, C. A. S., \& Sartori, D. J. (2016). Immediate effects of the semi-occluded vocal tract exercise with LaxVox tube in singers. Codas, 28(5), 618-624.

Fernandes, F. E., Martins, S. R. G., \& Bonvent, J. J. (2007). Efeito do treinamento muscular respiratório por meio do manovacuômetro e do Threshold Pep em pacientes hemiparéticos hospitalizados. IFMBE Proceedings, 18, 1199-1202.

Gillivan-Murphy, P., Drinnan, M. J., O’Dwyer, T. P., Ridha, H., \& Carding, P. (2006). The effectiveness of a voice treatment approach for teachers with self-reported voice problems. Journal of Voice, 20(3), 423-431.

Guzman, M., Calvache, C., Romero, L., Muñoz, D., Olavarria, C., Madrid, S.,
... \& Bortnem, C. (2015). Do different semi-occluded voice exercises affect vocal fold adduction differently in subjects diagnosed with hyperfunctional dysphonia? Folia phoniatrica et Logopaedica, 67(2), 68-75.

Han, J. Y., \& Jeong, O. R. (2002). Voice intervention of professional voice users with a holistic voice management program. Journal of Speech \& Hearing Disorders, 11(2), 141-174.

Hirano, M. (1981). Psycho-acoustic evaluation of voice. In Clinical examination of voice (pp. 81-84). New York, NY: Springer.

Hogikyan, N. D., \& Sethuraman, G. (1999). Validation of an instrument to measure voice-related quality of life (V-RQOL). Journal of Voice, 13(4), 557-569.

Huh, M. J. (2017). Relationship between inspiratory muscle training and phonation performance. The Study of Education for Hearing-Language Impairments, 8(2), 81-92.

Jacobson, B. H., Johnson, A., Grywalski, C., Silbergleit, A., Jacobson, G., Benninger, M. S., \& Newman, C. W. (1997). The voice handicap index (VHI) development and validation. American Journal of Speech-Language Pathology, 6(3), 66-70.

Johnston, C. L., James, R., \& Mackney, J. H. (2013). The current use of positive expiratory pressure (PEP) therapy by public hospital physiotherapists in New South Wales. New Zealand Journal of Physiotherapy, 41(3), 88-93.

Kandogan, T., \& Sanal, A. (2005). Voice Handicap Index (VHI) in partial laryngectomy patients. KBB Forum, 4(1), 15-17.

Kim, J., \& Sapienza, C. M. (2006). Effects of expiratory muscle strength training with the healthy elderly on speech. Korean Journal of Communication \&Disorders, 11(2), 1-16.

Kim, J. O., Lim, S. E., Park, S. Y., Choi, S. H., Choi, J. N., \& Choi, H. S. (2007). Validity and reliability of Korean-version of Voice Handicap Index and voice-related quality of life. Speech Sciences, 14(3), 111-125.

Kim, J. S., Lee, D. W., Choi, C. H., \& Choi, S. H. (2017). Effects of laryngeal massage and semi-occluded vocal tract exercises for patients with hyperfunctional dysphonia. Communication Sciences \& Disorders, 22(4), 806817.

Kwon, S. B., Wang, S. G., Yang, B. G., \& Jeon, G. R. (2006). Effects of abdominal respiration and self voice feedback therapy on the voice improvement of patients with vocal nodules. Speech Sciences, 13(3), 133-153.

Lim, H. J., Choi, S. H., Kim, J. K., \& Choi, C. H. (2016). Effects of Lax Vox voice therapy in a patient with spasmodic dysphonia: a case report. Phonetics and Speech Sciences, 8(2), 57-63.

Lim, H. J., Kim, J. K., Kwon, D. H., \& Park, J. Y. (2009). The effect of vocal 
function exercise on voice improvement in patients with vocal nodules. Phonetics and Speech Sciences, 1(2), 37-42.

Moon, Y. I., Chung, S. M., Kim, M. J., \& Kim, Y. J. (1999). Aerodynamic and acoustic analysis of respiration and phonation methods in normal adults. Korean Journal of Otorhinolaryngology-Head and Neck Surgery, 42(6), 756761.

Nguyen, D. D., \& Kenny, D. T. (2009). Randomized controlled trial of vocal function exercises on muscle tension dysphonia in Vietnamese female teachers. Journal of Otolaryngology-Head \& Neck Surgery, 38(2), 261-278.

Philips Respironics. (2013). Pressure that's good for you: threshold PEP and IMT. https://www.philips.co.uk/c-dam/b2bhc/master/whitepapers/copd/ 1036501_ThresholdIMT_SalesAid.pdf

Roy, N., Gray, S. D., Simon, M., Dove, H., Corbin-Lewis, K., \& Stemple, J. C. (2001). An evaluation of the effects of two treatment approaches for teachers with voice disorders. Journal of Speech, Language, and Hearing Research, 44(2), 286-296.

Sabol, J. W., Lee, L., \& Stemple, J. C. (1995). The value of vocal function exer- cises in the practice regimen of singers. Journal of Voice, 9(1), 27-36.

Stemple, J. C., Lee, L., D’Amico, B., \& Pickup, B. (1994). Efficacy of vocal function exercises as a method of improving voice production. Journal of Voice, 8(3), 271-278.

Tsai, Y. C., Huang, S., Che, W. C., Huang, Y. C., Liou, T. H., \& Kuo, Y. C. (2016). The effects of expiratory muscle strength training on voice and associated factors in medical professionals with voice disorders. Journal of Voice, 30(6), 759.e21-759.e27.

Wingate, J. M., Brown, W. S., Shrivastav, R., Davenport, P., \& Sapienza, C. M. (2007). Treatment outcomes for professional voice users. Journal of Voice, 21(4), 433-449.

Yoo, J. Y., \& Lee, H. N. (2018). A case study on vocal aerobic treatment voice therapy development and application for classical singers. Journal of Rehabilitation Research, 22(1), 157-168.

Yun, Y. S., Kim, H., Son, Y. I., \& Choi, H. S. (2008). Validation of the Korean Voice Handicap Index (K-VHI) and the clinical usefulness of Korean VHI10. Korean Journal of Communication \& Disorders, 13(2), 216-241. 
Ha-Neul Kang, et al. • Effects of Voice Therapy Using Respiration Trainer

Appendix 1. 호흡훈련기를 활용한 음성치료 프로그램

1) 호흡훈련기를 활용한 VAT 프로그램 절차 및 활동(예시)

\section{호흡훈련기를 활용한 VAT 프로그램}

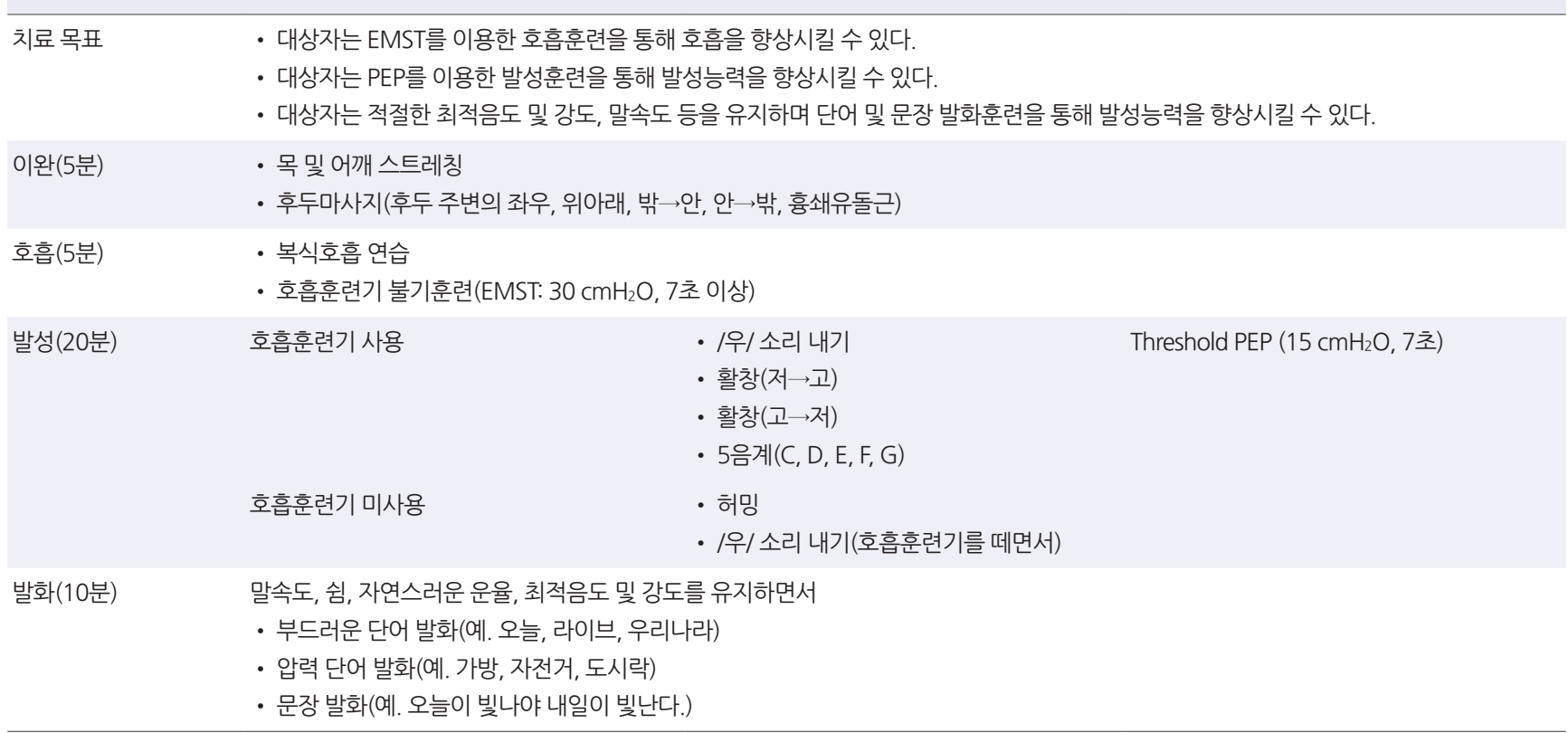


2) 음성치료 활동지

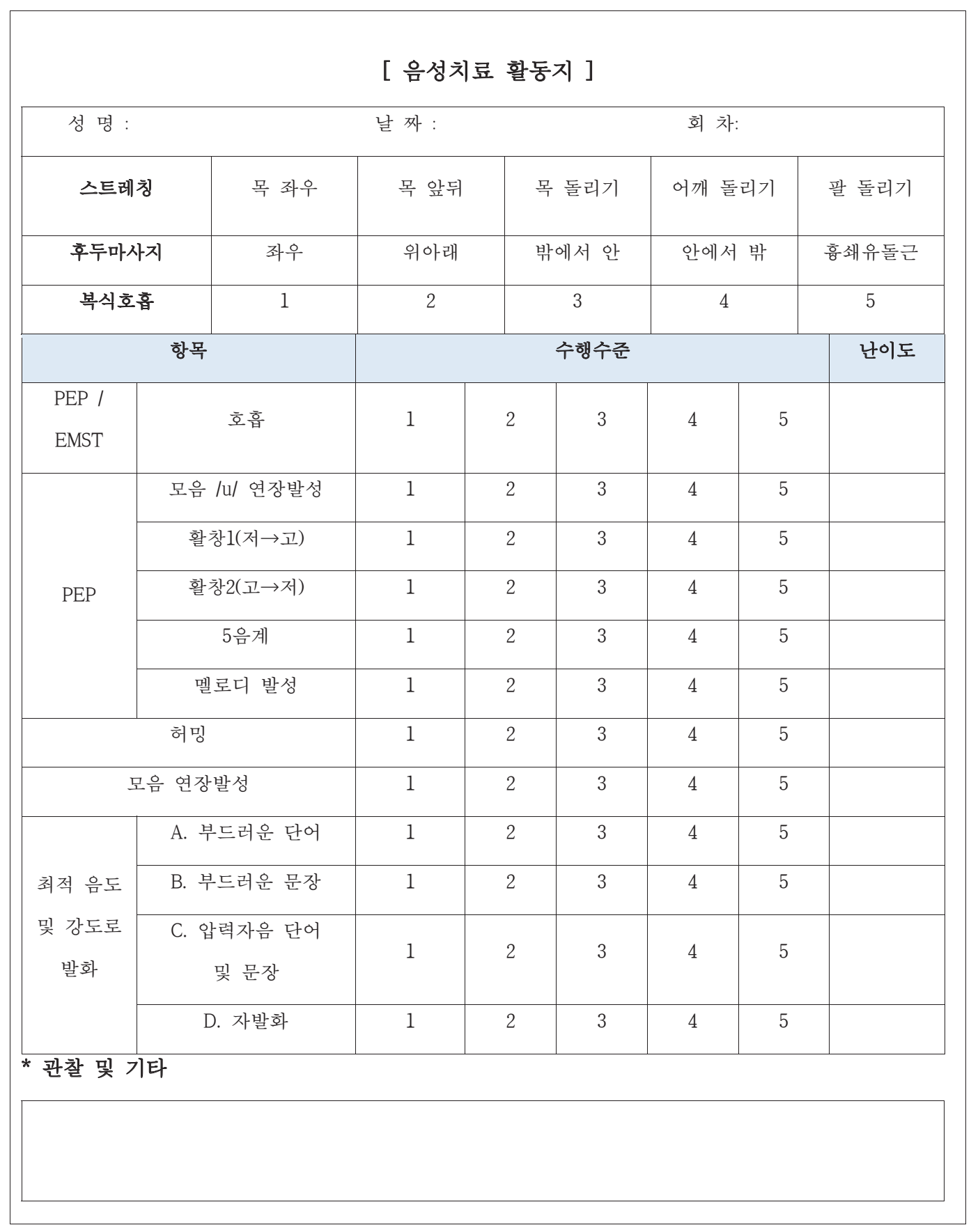




\section{국문초록}

\section{호흡훈련기를 활용한 성대에어로빅치료 프로그램의 음성개선 효과 사례연구 강하늘 ${ }^{1}$ 유재연 ${ }^{2}$ \\ '호남대학교대학원 재활과학과 언어치료전공, ${ }^{2}$ 호남대학교 언어치료학과}

배경 및 목적: 본 연구는 재활치료 분야에서 널리 사용되고 있는 호흡훈련기를 최근에 개발된 총체적 음성치료인 성대에어로빅치료 프로그램에 접목시켜 활용하고자 하였다. 이에 호흡훈련기를 활용한 VAT 프로그램을 음성장애인에게 적용하여 음성개선의 효과를 알아보고자 하였다. 방법: 본 연구는 과기능적 음성장애인 4 명(여 3 명, 남 1 명)을 대상으로 하였고 호흡훈련기를 활용한 VAT 프로그램 은 이완단계, 호흡단계, 발성단계, 발화단계로 구성되어 있다. 음성개선의 정도를 살펴보기 위해 사전·중재·사후로 음향학적 및 공기역 학적 매개변수의 변화를 살펴보고 사전·사후로 음성설문지, 청지각적 평가를 실시하여 비교하였다. 결과: 본 프로그램을 적용한 결과, 음도와 발화음도가 전반적으로 상승하고 음역대가 넓어졌으며 음향학적 매개변수 수치가 감소하여 음질이 향상되었다. 또한 공기역학 적 매개변수가 개선되어 호흡능력이 향상되었고 음성장애지수가 감소하고 음성관련 삶의 질이 높아져 음성만족도가 높아졌다. 대상자 들은 좀 더 편안하고 부드러운 음성을 산출하여 청지각적으로도 음성이 개선되었다. 논의 및 결론: 호흡훈련기를 활용한 VAT 프로그 램은 과기능적 음성장애인의 음성을 개선시키는 데 효과적이었으며 음성치료 분야에서 유용하게 사용될 수 있는 프로그램으로 보여 진다. 차후에는 더 다양하고 많은 대상자를 중심으로 본 프로그램을 실시한다면 음성치료에 유용한 정보를 제공할 수 있을 것이다.

핵심어: 호흡훈련기, VAT 프로그램, 과기능적 음성장애, 음성치료

본 논문은 제 1 저자의 석사학위논문을 수정·보완하였음.

\section{참고문헌}

권순복, 왕수건, 양병곤, 전계록(2006). 복식호흡 훈련과 Self Voice Feedback 프로그램이 성대결절 환자의 음성개선에 미치는 효과. 음성과학, 13(3), 133-153.

김재옥, 임성은, 박선영, 최성희, 최재남, 최홍식(2007). 한국어판 음성장애지수와음성관련 삶의 질의 타당도 및 신뢰도 연구. 음성과학, 14(3), 111-125. 김지성, 이동욱, 최철희, 최성희(2017). 후두마사지와 반폐쇄성도훈련이 과기능적 음성장애 환자의 음성개선에 미치는 효과. Communication Sciences \& Disorders, 22(4), 806-817.

문영일, 정성민, 김문정, 김유정(1999). 정상 성인의 호흡과 발성 방법에 따른 공기역학적 및 음향학적 변화에 대한 연구. 대한이비인후과학회지 두경 부외과학, 42(6), 756-761.

유재연, 이하나(2018). 성악가를 위한 VAT 음성치료 개발 및 적용 사례연구. 재활복지, 22(1), 157-168.

윤영선, 김향희, 손영익, 최홍식(2008). 한국어판 음성장애지수(Voice Handicap Index, VHI)의 타당도 및 VHI-10의 임상적 유용성. 언어청각장애연 구, 13(2), 2016-241.

임혜진, 김정규, 권도하, 박준영(2009). 성대 기능 훈련이 성대결절 환자의 음성개선에 미치는 효과. 말소리와 음성과학, 1(2), 37-42. 임혜진, 최성희, 김정규, 최철희(2016). 연축성 발성장애 환자의 Lax Vox 음성치료 효과. 말소리와음성과학, 8(2), 57-63. 한지용, 정옥란(2002). 총체적 음성관리 프로그램을 통한 직업적 음성사용자의 음성중재. 언어치료연구, 11(2), 141-174. 허명진(2017). 흡기근 강화훈련이 만성 뇌졸중 환자의 발성 산출에 미치는 영향. 한국청각언어장애교육연구, 8(2), 81-92.

\section{ORCID}

강하늘(http://orcid.org/0000-0003-0133-2894); 유재연(http://orcid.org/0000-0001-5575-1280) 